\title{
Article \\ Renewable Energy System Controlled by Open-Source Tools and Digital Twin Model: Zero Energy Port Area in Italy
}

\author{
Sofia Agostinelli ${ }^{1}$ (D), Fabrizio Cumo ${ }^{2, *}$, Meysam Majidi Nezhad ${ }^{1}$, Giuseppe Orsini ${ }^{1}$ and Giuseppe Piras ${ }^{1}$ (D) \\ 1 Department of Astronautics, Electrical and Energy Engineering (DIAEE), Sapienza University of Rome, \\ 00184 Roma, Italy; sofia.agostinelli@uniroma1.it (S.A.); meysam.majidinezhad@uniroma1.it (M.M.N.); \\ giuseppe.orsini@uniroma1.it (G.O.); giuseppe.piras@uniroma1.it (G.P.) \\ 2 CITERA Research Centre, Sapienza University of Rome, 00197 Rome, Italy \\ * Correspondence: fabrizio.cumo@uniroma1.it
}

check for

updates

Citation: Agostinelli, S.; Cumo, F.; Nezhad, M.M.; Orsini, G.; Piras, G. Renewable Energy System Controlled by Open-Source Tools and Digital Twin Model: Zero Energy Port Area in Italy. Energies 2022, 15, 1817. https://doi.org/10.3390/ en15051817

Academic Editors: Andrea Mauri, Benedetto Nastasi and Gerardo Maria Mauro

Received: 10 January 2022 Accepted: 25 February 2022 Published: 1 March 2022

Publisher's Note: MDPI stays neutral with regard to jurisdictional claims in published maps and institutional affiliations.

Copyright: (C) 2022 by the authors. Licensee MDPI, Basel, Switzerland. This article is an open access article distributed under the terms and conditions of the Creative Commons Attribution (CC BY) license (https:// creativecommons.org/licenses/by/ $4.0 /)$.

\begin{abstract}
The present paper deals with an infrastructure digitization policy to optimize maintenance processes and energy efficiency to transform port areas to ZED (Zero Energy District). The Lazio Region started the process for all its ports in 2020. The Anzio port started and developed as a pilot project as it is a particularly representative sample for the Mediterranean Sea reality due to its geomorphological conformation. The study aimed to develop energy-saving procedures and strategies and integrate production systems from Renewable Energy Systems (RESs) for sustainable mobility. In the article, these strategies are described in detail and energy analysis is carried out, starting from the current state and demonstrating the potential energy self-sufficiency of the infrastructure. Finally, the investigation's potential utilizing a Digital Twin (DT) of the area is highlighted. Furthermore, the BIM (Building Information Modeling) and GIS (Geographic Information System) combining possibility to maximize the energy efficiency measures beneficial impact are discussed.
\end{abstract}

Keywords: Renewable Energy Systems (RESs); Zero Energy District (ZED); Digital Twin (DT); Building Information Modelling (BIM); Geographic Information System (GIS); Revit software's

\section{Introduction}

Increasing energy demand due to human society's population growth has led to rising energy prices [1], pollution and Greenhouse Gas (GHG) emissions. In this case, energy costs can be a significant overhead for ports [2]. Reducing GHG emissions and air pollution directly contributes to ports sustainability and green landscape [3]. Energy efficiency in ports is mainly related to providing the same services with less energy consumption and Renewable Energy Sources (RESs) and environmentally friendly [4]. Energy efficiency has a critical role for ports to reduce energy consumption and provide environmentally friendly services. The weather conditions that can influence port policymakers, sustainability and adaptation strategies are vital to helping create green ports [5]. Since many of the ports are located near large cities, they play an essential role in air pollution [6-8]. Ports, especially container ports, have three functional areas: quayside, yard, and landside $[9,10]$. Reducing GHG and pollutant emissions directly results from energy efficiency, equipment electrification, alternative fuels [11] and RESs. Along with increasing operational efficiency, these aspects can form a large part of the ports concept in the next generation [12].

There is a strong relationship between port operational efficiency and port energy efficiency. The increased operational efficiency of sources reduces energy consumption and significantly increases energy efficiency in ports [13]. Energy consumption in ports can be either electricity or fossil fuel. In recent years, practical steps have been taken to electrify equipment using electricity generated in ports through RESs, including the increasing advances in electricity generation, storage, distribution, conversion, and consumption technologies [14]. Furthermore, those technologies used in ports can significantly increase 
energy efficiency [15]. The significant increase in renewable energy technology, accompanied by the control technologies development and the converter installation, has led to the development efforts to develop energy in ports considering the existing potential [16].

Today, new technologies can increase energy efficiency and reduce GHG emissions in ports as solutions. On the other hand, using boats and ships with electricity can prevent severe marine pollution caused by oil spills. These solutions include the electricity use as RESs for independent vehicles, energy storage devices, cooling technologies and clean fuels such as cold-ironing [17], equipment [18,19], reefer containers [19], technologies in lighting. This technological improvement can dramatically guarantee energy efficiency using the Light-Emitting Diode (LED) lamps instead of high-pressure sodium lamps in port storage facilities, management buildings, high lighting towers in the wind space terminal [20]. For example, the Netherlands Delta terminal uses LED bulbs to save $922 \mathrm{MWh}$ of annual power consumption, equivalent to $€ 300,000$ [21]. In addition to using LED technology, focusing on lighting levels and designing armatures in ports can help save energy.

Renewable energies have been evaluated and identified as clean sources, such as tidal [22] and wave energy [23], geothermal energy [24], wind [25], and solar energy [26,27] are available due to the geographical location areas for ports. Many studies are addressing port energy management such as the ports of Singapore [28], Hamburg [29], Rotterdam in the Netherlands [30], Antwerp [31], Istanbul [32], Lübeck [8], Vancouver [33], La Spezia [34]. Sadek et al. [35] focused on RESs to replace fossil fuels of the Mediterranean ports. The offshore wind turbines and fuel cell units have been used as two examples of energy sources in ports. Their research shows that the combined system of wind turbines and fuel cells is the best choice for the unit cost of electricity generation with 0.101 and 0.107 of Alexandria port. Furthermore, they state that using fuel cells [36] and offshore wind turbines [37] as a green power concept will reduce " $\mathrm{CO}_{2}$ ", "NOx" and "CO" emissions per year. Finally, they point to using a combination of renewable energy and green energy supply in the port of Alexandria, possibly reducing $22.31 \%$ of annual electricity costs.

In this regard, maritime transport is under increasing pressure to reduce the harmful effects of climate and the environment. Maritime transport can be responsible for $10 \%$ to $15 \%$ of the annual emissions of sulfur (SOx) and nitrogen oxides (NOx) and also approximately $3 \%$ of the global carbon dioxide $\left(\mathrm{CO}_{2}\right)$ emissions [38]. In 2018, the International Maritime Organization (IMO) member states set a $50 \%$ reduction in greenhouse gas emissions by 2050 compared to 2008, referred to as the "Paris Agreement on Shipping". Achieving this goal in 2050 requires the different sectors' strenuous installation and development of new technologies and other political measures by governments to adopt the maritime sector to zero emissions [39]. Hence, five critical factors in reducing port pollution have been identified by the World Port Climate Declaration at the international level: (1) reduce $\mathrm{CO}_{2}$ from ships that sail the long and deep sea to ports, (2) evaluate how $\mathrm{CO}_{2}$ is reduced from port operations, (3) evaluate how $\mathrm{CO}_{2}$ is reduced from inland shipping, (4) study how to use RESs as an alternative way, and (5) further develop methods for calculating $\mathrm{CO}_{2}$ in ports [34].

The Digital Twin (DT) system can be proposed essentially based on integration of softwares that has already been used, such as Building Information Modelling (BIM) and Geographic Information System (GIS). In addition, sensors aimed at the database implementing [40] and the functioning Artificial Intelligence (AI) systems optimizing [41] can be inserted in a sharing platform and powered in real-time by a series of the Internet of Things (IoT). The simulations can be carried out using specific, compatible tools that will allow the use of the DT in multiple fields of study, from architecture to engineering and economics [42]. Implementing a systemic, digital approach applied to industrial areas and urban systems produces diversified digital city models [43] based on the scale of analysis [44]. The DT methodology presents the traditional urban basis map's evolution and progressive technological transformation and is developed, managed [45], and constantly monitored in three dimensions through models based on intelligent geo-databases [46]. 
In buildings, energy-related parameters can be linked to the DT building portion of the neighborhood to monitor energy consumption, related costs and optimization [47]. Opening up renewed scenarios such as intelligent and evolutionary cities, and these monitoring possibilities can find application in the management of individual infrastructures or more extensive scale of entire commercial and industrial areas. Creating an information model based on objects, specific properties and attributes to develop an accurate DT model [48], means configuring a tool for analysing and evaluating possible scenarios supporting the decision-making process. Information models are powered by a constant flow of data generated [49] to update the DT model in real-time of the main digital model, i.e., sensors, cameras and smart grids [50]. The DT model can progressively collect a large number of data using sensors installed inside the buildings and port infrastructures, returning a virtual mirror of reality at any time. In particular, the DT thus collects operational and environmental information in the process components [51], later processed with analytical techniques and algorithmic simulations.

This study aims to develop energy-saving and increase energy efficiency methods and strategies using the RESs integration production systems in the energy ports. Firstly, energysaving strategies are described in energy analysis detail [52]. Furthermore, the research potential of DT has been through the integration of BIM and GIS software. Secondly, several open-source (online and free access) platform-tools have been used to evaluate the Anzio port's wind and solar energy potential. Finally, these open-source platform tools are used to discover, extract, and process RESs data mapping, assessment and modelling to understand better the port of Anzio with very high time resolution data.

This paper is organized as follows: Section 2 explains the materials and methods, Section 3 describes the Anzio port as a case study, the results are provided in Section 4. Section 5 presents research discussion and Section 6 presents conclusions.

\section{Materials and Methods}

The DT includes a physical model, a virtual model and a connection between the physical and virtual models. In particular, several online open-platform data such as "Renewables. Ninja", "RSE Wind Atlas" platforms and MERRA-2 reanalysis data were used as input data of three software types such as, BIM, GIS and Revit software were used for analysis and integrating the model.

\subsection{Efficient Strategies Development and DT Model}

Firstly, the IoT data is collected through sensors and actuators sharing information to the DT in the cloud. Furthermore, the DT simulates its operation based on the information collected and uses these simulations either as a benchmark for comparison with the actual performance or to modify the operation/setting of the duplicated physical object.

The realisation of the DT model related to the product, system, organisation or activity process investigated. In the case of DT in the urban context, the idea of "Smart City" is the focus of this study. The model can be created using BIM software, such as Graphisoft ArchiCAD and Autodesk Revit (Figure 1).

Furthermore, the efficient strategies developed through the identification of individual technologies able to reduce consumption (e.g., lighthouse towers equipped with LightEmitting Diode (LED) lighting) (Figure 2) and through energy diagnoses on buildings performances using dedicated software such as MC4 and TerMus. Autodesk's simulation engine, Green Building Studio (GBS), has been utilized; it enables the energy analysis functions in Revit and Insight, the web interface for interacting with the results produced by GBS.

As an example, the use of the electric multi-scale digital BIM and GIS model allows the detailed analysis of energy consumption, both through a punctual computation of all local loads such as lighting fixtures and electric recharging columns for boats and through the calculation of the actual consumption of public buildings [51] in the area (harbour master's office, ticket office, etc.). 
The inclusion of appropriate shared parameters in the BIM model has allowed a detailed calculation [53], estimate and description of the energy consumption associated with the various facilities in the port area. For example, the consumption of the lighting terminals, which is about $67 \%$ of the total electrical consumption (see Table 1 ), is shown below.
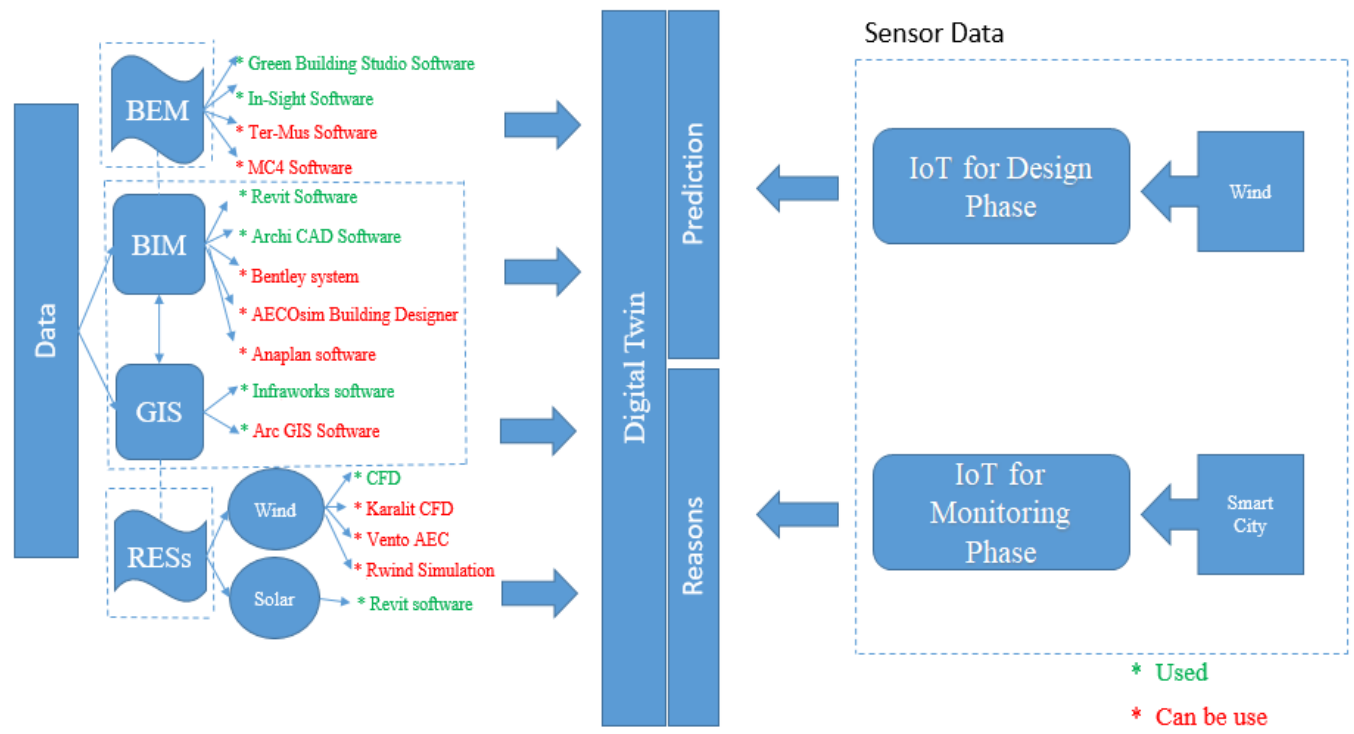

Figure 1. The main stages of the method developed in the port of Anzio. The software's used in this research is shown in green and the software's that can be used is shown in red.
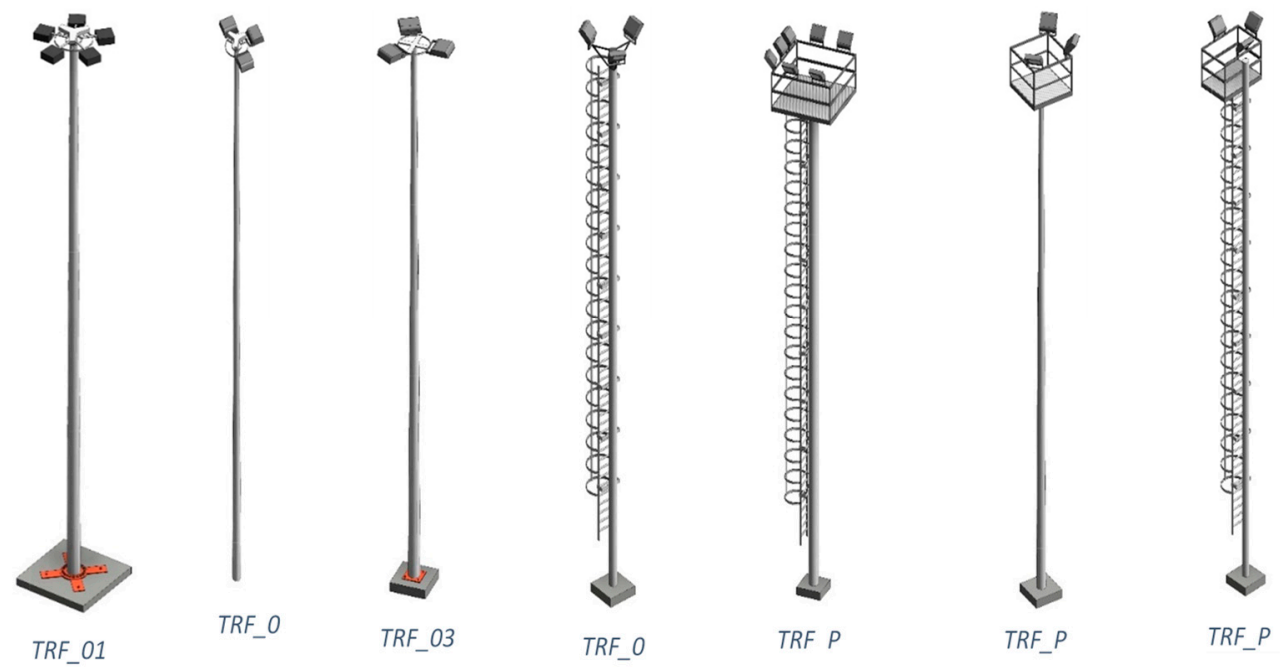

Figure 2. The lighting structures under studies.

The consequent efficiency improvement hypothesis by replacing the old energyconsuming floodlights of the light towers LED lighting structures is shown in Figure 2. The total load, following the efficiency measures, is therefore equal to:

$$
C_{l}+C_{c r}
$$

With $C_{I}$ the consumption of the new lighting system and $C_{c r}$ that of the charging stations. Therefore, after the interventions, the overall energy saved is equal to:

$$
E_{A O}-E_{P O}=M W h \text { per Year }
$$

where $E_{A O}$ and $E_{P O}$ represent the pre- and post-construction consumption respectively. 
Table 1. Actual electrical load lighting system of the Anzio port.

\begin{tabular}{|c|c|c|c|c|c|c|c|c|c|c|}
\hline \multicolumn{11}{|c|}{ Existing Phase-Consumption Estimate-Lighting } \\
\hline Data Sheet & Description & $\begin{array}{l}\text { Family and } \\
\text { Type }\end{array}$ & Quantity (n) & Spotlight (n) & $\begin{array}{l}\text { Spotlight } \\
\text { Power (W) }\end{array}$ & Type Power (W) & $\begin{array}{l}\text { Total Power } \\
\text { (W) }\end{array}$ & $\begin{array}{l}\text { Hours of Use } \\
\text { (h) }\end{array}$ & Days of Use (n) & $\begin{array}{c}\text { Annual } \\
\text { Consumption } \\
\text { (Wh) }\end{array}$ \\
\hline STF-A_004.1 & Streetlight & LMP_01: H_4m & 3 & 1 & 60 & 60 & 180 & 10 & 365 & 657,000 \\
\hline STF-A_004.2 & Streetlight & LMP_02: H_6m & 18 & 1 & 80 & 80 & 1440 & 10 & 365 & $5,256,000$ \\
\hline STF-A_004.3 & Streetlight & $\begin{array}{c}\text { LMP_03: H_6m - } \\
\text { 3_Proiettori }\end{array}$ & 4 & 3 & 100 & 300 & 1200 & 10 & 365 & $4,380,000$ \\
\hline STF-A_004.4 & Streetlight & LMP_04: H_3m & 2 & 1 & 80 & 80 & 160 & 10 & 365 & 584,000 \\
\hline STF-A_004.5 & Streetlight & LMP_05: H_3m & 12 & 1 & 100 & 100 & 1200 & 10 & 365 & $4,380,000$ \\
\hline STF-A_004.7 & Streetlight & $\begin{array}{l}\text { LMP_07: H_6m - } \\
\text { 1_Proiettore }\end{array}$ & 3 & 1 & 100 & 100 & 300 & 10 & 365 & $1,095,000$ \\
\hline STF-A_004.8 & Streetlight & $\begin{array}{l}\text { LMP_07: H_6m - } \\
\text { 2_Proiettori }\end{array}$ & 1 & 2 & 100 & 200 & 200 & 10 & 365 & 730,000 \\
\hline STF-A_005.1 & $\begin{array}{l}\text { Light tower } \\
\text { with platform }\end{array}$ & $\begin{array}{c}\text { TRF_P_01: } \\
\text { H_12m - } \\
\text { 7_Proiettori }\end{array}$ & 1 & 7 & 850 & 5950 & 5950 & 10 & 365 & $21,717,500$ \\
\hline STF-A_005.2 & $\begin{array}{l}\text { Light tower } \\
\text { with platform }\end{array}$ & $\begin{array}{l}\text { TRF_P_02: } \\
\text { H_12m - } \\
\text { 3_Proiettori } \\
\text { TRF P 03: }\end{array}$ & 1 & 3 & 850 & 2550 & 2550 & 10 & 365 & $9,307,500$ \\
\hline STF-A_006.1 & Light tower & $\begin{array}{l}\text { TRF_01: H_12m } \\
\text { - 3_Proiettori }\end{array}$ & 7 & 3 & 850 & 2550 & 17,850 & 10 & 365 & $65,152,500$ \\
\hline STF-A_006.2 & Light tower & $\begin{array}{l}\text { TRF_01: H_12m } \\
\text { - 5_Proiettori }\end{array}$ & 6 & 5 & 850 & 4250 & 25,500 & 10 & 365 & $93,075,000$ \\
\hline STF-A_006.3 & Light tower & $\begin{array}{l}\text { TRF_02: H_12m } \\
\text { - 2_Proiettori }\end{array}$ & 1 & 2 & 850 & 1700 & 1700 & 10 & 365 & $6,205,000$ \\
\hline STF-A_006.4 & Light tower & $\begin{array}{l}\text { TRF_02: H_12m } \\
\text { - 3_Proiettori }\end{array}$ & 1 & 3 & 850 & 2550 & 2550 & 10 & 365 & $9,307,500$ \\
\hline STF-A_006.5 & Light tower & $\begin{array}{l}\text { TRF_03: H_12m } \\
\text { - 3_Proiettori }\end{array}$ & 2 & 3 & 850 & 2550 & 5100 & 10 & 365 & $18,615,000$ \\
\hline STF-A_006.6 & Light tower & $\begin{array}{l}\text { TRF_04: H_12m } \\
\text {-3_Proiettori }\end{array}$ & 1 & 3 & 850 & 2550 & 2550 & 10 & 365 & $9,307,500$ \\
\hline STF-A_007.1 & Signal light & FRR: H_4m & 1 & 1 & 100 & 100 & 100 & 10 & 365 & 365,000 \\
\hline \multirow[t]{3}{*}{ STF-A_007.2 } & Signal light & FRV: H_4m & 1 & 1 & 100 & 100 & 100 & 10 & 365 & 365,000 \\
\hline & & & & & & & 71,500 & & & $260,975,000$ \\
\hline & & & & & & & & & & $260,975 \mathrm{kWh}$ \\
\hline
\end{tabular}




\subsection{Wind Energy Potential Assessment}

In this context, MERRA-2 reanalysis data has been used to wind speed potential mapping and time series analysis of the areas of Anzio port over 41 years between 1980 to 2021. The wind speed time-series analysis and mapping can help in decision-making about the RESs in the Anzio port areas.

Furthermore, the numerical analysis, the MATLAB software "Curve Fitting Toolbox" tool used to obtain the value of the annual energy produced. With the turbine control, it is possible to produce:

$$
N_{t} \times E_{t}(k W h) \text { per year }
$$

With $N_{t}$ the number of devices and $E_{t}$ the energy produced in a year by each of them.

\subsection{Solar Energy Potential Assessment}

MERRA-2 reanalysis data has been used for solar irradiation potential analysis of the areas of Anzio port over 41 years between 1980 to 2021. The solar energy sources time-series analysis and mapping can help decision-making and better understand the RESs in the Anzio port areas.

In this step, two areas for installing solar panels have been investigated, (i) Photovoltaic (PV) asphalt, (ii) the parking PV shelter.

Finally, the total area of the PV plant was calculated:

$$
S=\frac{P_{p}}{\eta}=m^{2}
$$

where $P_{p}$ is the peak power of the system and $\eta$ the average yield of the modules. With the same energy produced with solar asphalt:

$$
P_{p}=\frac{E_{a s}}{E_{1 k w(p)}} \approx k W p
$$

With $E_{a s}$ the electricity produced overall by the solar asphalt and $E_{1 k W p(p e n s)}$ produced by a $1 \mathrm{kWp}$ system mounted on the shelters. Therefore, the number of shelters can be easily calculated:

$$
\frac{P_{p}}{P_{p p}}=P V
$$

Since each shelter covers an area of $50 \mathrm{~m}^{2}$, the surface occupied by all the infrastructure is equal to:

$$
S_{p} \times N_{p}=m^{2}
$$

Corresponding exactly to that of the parking area identified.

\subsection{Energy Produced Balance}

The total energy produced by the two RESs, it means wind and solar is equal to:

$$
E_{f}+E_{e}=M W h \text { per year }
$$

The goal of transforming the area into a ZED has been achieved. The optimized annual energy requirement of the port area is fully covered by the on-site production of wind and photovoltaic systems.

$$
E_{F E R}+C=+2.8 M W h \text { per year }
$$

With $E_{F E R}$ the energy produced from RESs and C the consumption of the port.

\section{5. $\mathrm{CO}_{2}$ Emissions Avoided}

The energy upgrading of the port area can significantly contribute to the reduction of $\mathrm{CO}_{2}$ emissions and the reduction of energy absorption from the national electricity grid. 
The calculation of avoided $\mathrm{CO}_{2}$ emissions consists of the electricity generated from RESs by the average annual $\mathrm{CO}_{2}$ emission factor associated with the electricity grid.

The table with the emission factors, taken from the "Joint Research Center", shows the quantity in tons of $\mathrm{CO}_{2}$ emitted per MWh of energy produced by some energy carriers. Therefore, first of all, it is possible to calculate the $\mathrm{CO}_{2}$ not emitted as a result of the area's consumption reduction interventions:

$$
C_{a-p} \times F_{r e}=t \operatorname{Per} \mathrm{CO}_{2}
$$

where $C_{a-p}$ is the difference in pre- and post-construction consumption, and $F_{r e}$ is the considered emission factor. On the other hand, the share of $\mathrm{CO}_{2}$ emissions not emitted into the environment following the installation of RESs, is equal to:

$$
E_{F E R} \times F_{r e}=t \operatorname{Per} \mathrm{CO}_{2}
$$

With $E_{r e}$, the energy produced by RESs. Therefore, the $\mathrm{CO}_{2}$ not released into the environment compared to the starting situation is:

$$
\mathrm{CO}_{2 e}+\mathrm{CO}_{2 F E R}=t \operatorname{Per} \mathrm{CO}_{2}
$$

To this value, an additional quantity of $\mathrm{CO}_{2}$ not emitted into the environment should be added, i.e., that of the boats that would use the recharging service through the columns installed along the quays of the port (whose $\mathrm{CO}_{2}$ emission factors from the electricity network are in any case lower than those of conventional fuels).

Unfortunately, the estimation of the "carbon footprint" applied to boats parked on the quay or when approaching/leaving the port is a rather complex operation since the data relating to the turnout of boats in the harbour are not available. Furthermore, the environmental benefit of the measures adopted should be extended to the lack of emissions of pollutants such as $\mathrm{PM}_{2.5}$ and NOx from boats.

\section{Case Study}

Ports can be considered one of the most well-known places where human activities and environmental issues are indirect. Many important ports are focused on local and regional development and have been able to preserve local traditions for a long time because they are directly related to the development of their immediate city. Ports are therefore publicly owned in most parts of the world, although they have been privatized in the operational sector, which is usually required due to the nature, size, and long-term prospects of the investments required [54]. Hence, energy management plans in ports are highly dependent on energy management strategies in the nearby city [24]. Therefore, ports are directly dependent on the national electricity grid as an energy source to meet the needs of domestic electricity and ships stationed [35].

Anzio $\left(41^{\circ} 26^{\prime} 52.61^{\prime \prime} \mathrm{N}-12^{\circ} 37^{\prime} 44.59^{\prime \prime} \mathrm{E}\right.$ ) is a city with $43.43 \mathrm{~km}^{2}$ (16.77 sq $\mathrm{mi}$ ) and commune on the coast of the Lazio region of Italy, about $51 \mathrm{~km}$ (32 mi) south of Rome, Lazio (Latium) region, and located on a peninsula jutting into the Tyrrhenian Sea [55] (Figure 3). Anzio is a fishing port and a departure point well known for its seaside harbour setting for ferries and hydroplanes to the Pontine islands of Ponza, Palmarola, and Ventotene [56]. 


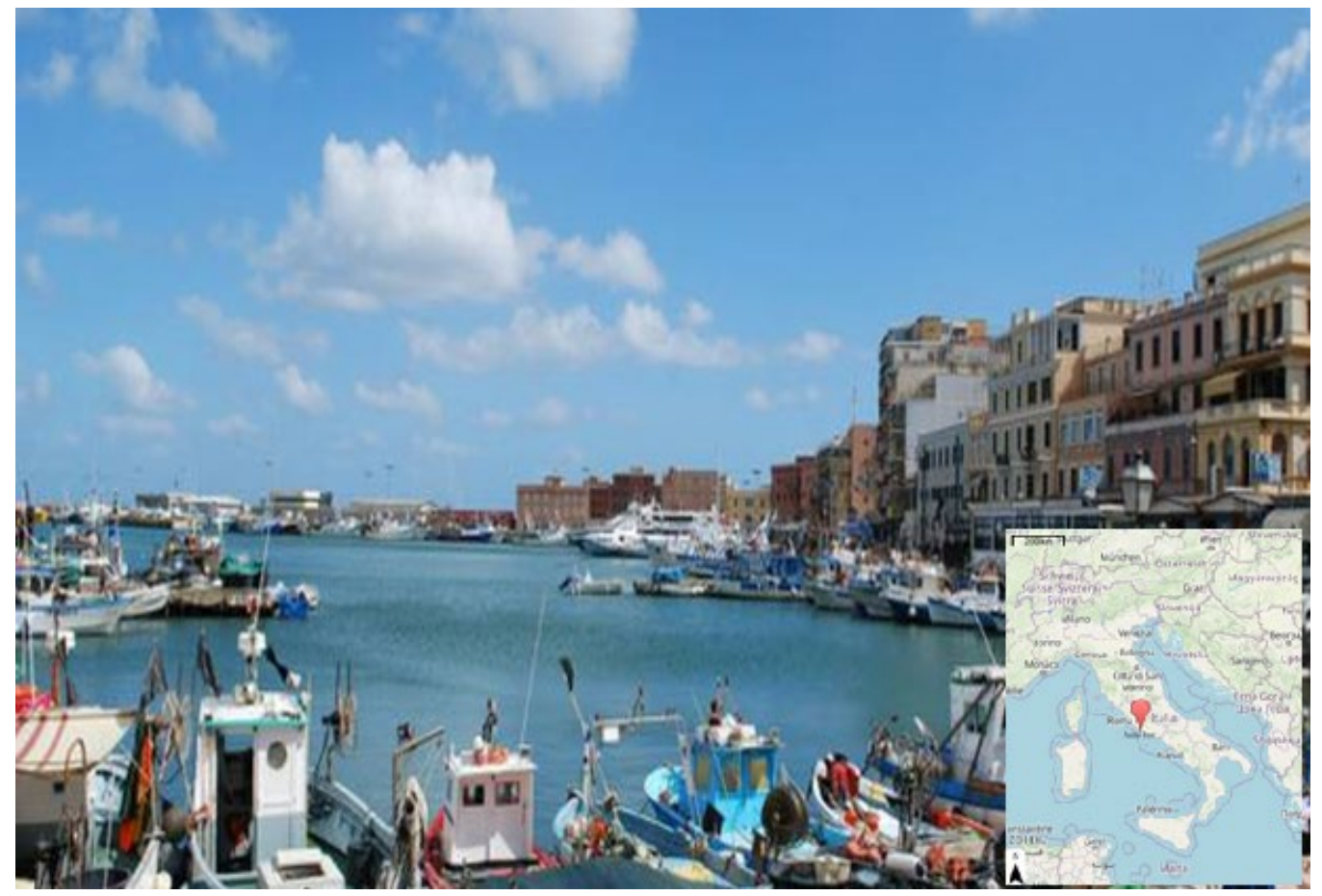

Figure 3. Anzio port.

\section{Results}

In this section, the research results are presented with a new integrated method using digital and RES models. These results offer practical strategies for evaluating wind and solar energy sources in ports to study the ZED.

\subsection{Integration of DT Models and LEDs}

The main objective of the DT framework is proposed to support decision-making using integrated multi-scale digital data sources, BIM and GIS information containers for simulation purposes about the implementation of strategies improving energy performance in the entire port area.

Future developments will integrate multi-scale digital simulations into real-time data. The digital models are structured to be interconnected to a cloud platform to acquire valuable data from the models and IoT sensors, configuring the effective DT.

Through Revit software, a series of distinct digital models were created by discipline (architectural, structural and MEP), each representing a specific "layer" within the overall digital model of the port area (Figure 4). Each of these models was then populated with three-dimensional families/objects, relative to the specific discipline under investigation, used as information containers.

Using the Industry Foundation Classes (IFC) file format allows exchanging information through a standard, open and non-proprietary format. As a result, it is possible to exploit all the BIM functionalities, generating an energy model of the building/plant system. Consequently, it is possible to analyse the actual state of different energy loads thanks to a detailed analysis of heating, hot water and cooling requirements in natural conditions, identifying and adjusting the most critical parts in the system's annual energy balance [57]. Once the efficiency of the entire port has been achieved, potential areas for the insertion of renewable energy production technologies are identified [58].

Similarly, with the interoperability between BIM and GIS, operated through Autodesk's Infra works software, the DT information is enriched with geospatial information describing the urban environment. This systems cooperation creates a reliable model where geographic information and design data are integrated to understand different asset interactions with the surrounding city. 


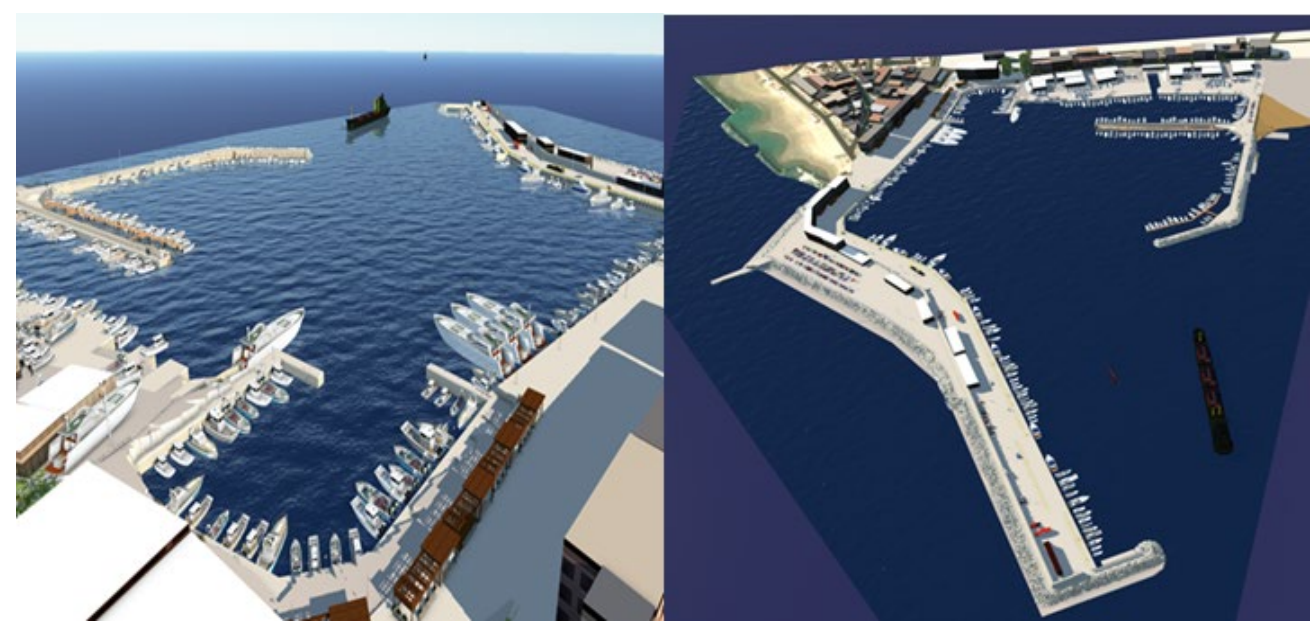

Figure 4. BIM model of the Anzio port area.

Among possible applications, GIS information can be exploited in a BIM process to improve energy savings. In this sense, GIS informs BIM that by exploiting data such as building heights and footprints, it is possible to identify areas with high energy loads or those with the highest priority for energy retrofitting [59].

The inclusion of appropriate shared parameters in the BIM model has allowed a detailed calculation, estimate and description of the energy consumption associated with the various facilities in the port area. The lighting terminals' consumption is about $67 \%$ of the total electrical consumption. The consequent efficiency improvement hypothesis is shown by replacing the old energy-consuming floodlights of the light towers with LED lighting structures. The results can be summarized as a reduction of about $65 \%$ in energy consumption for lighting than the current state as reported (Table 2).

In addition, some charging devices are installed in the Anzio port area for private and public boats (Figure 5). These devices are located in different places and divided into double charging stations and simple interlocked sockets.

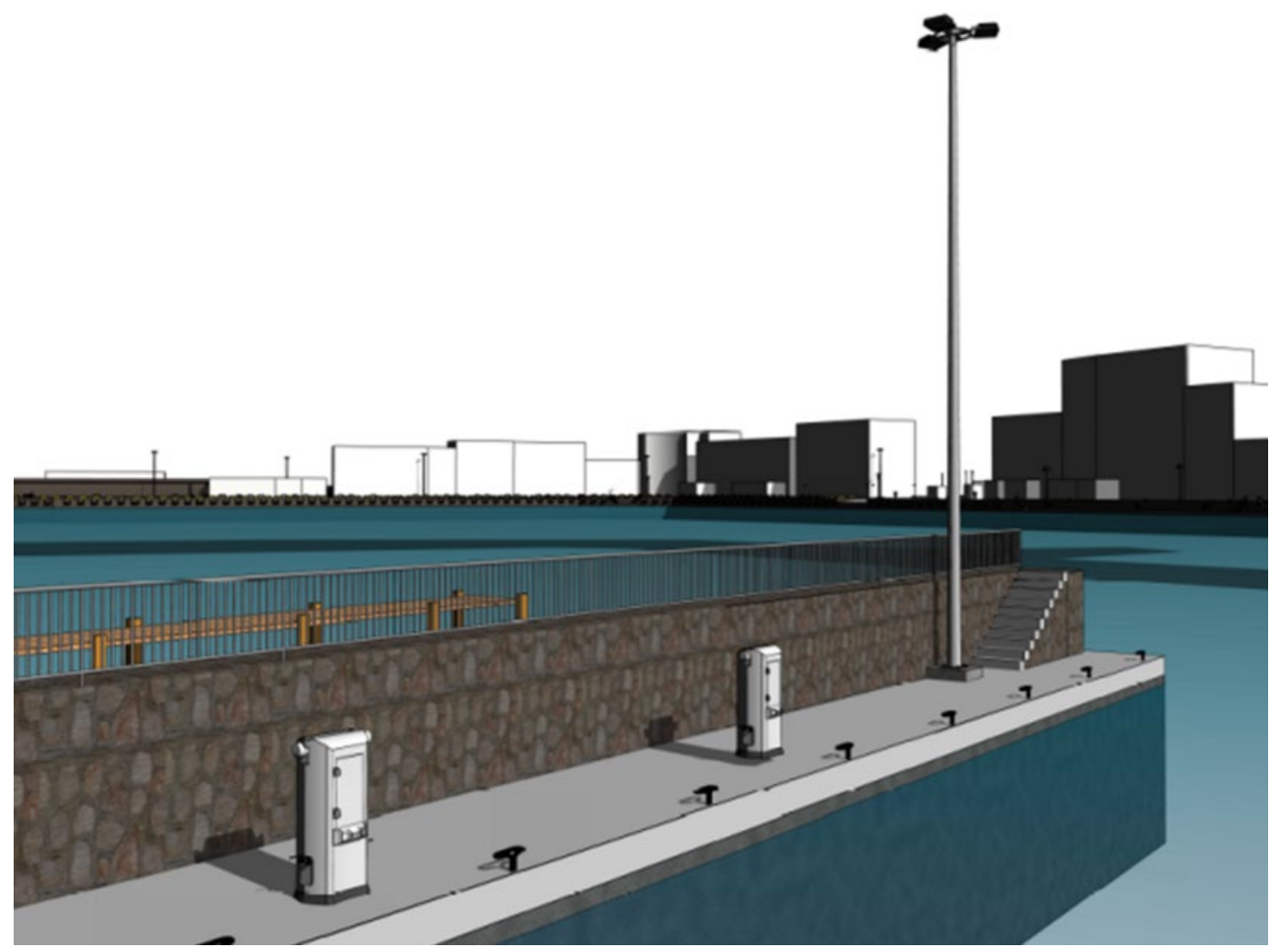

Figure 5. BIM model of the charging stations. 
Table 2. Optimized electrical load of the port lightning system.

\begin{tabular}{|c|c|c|c|c|c|c|c|c|c|c|}
\hline \multicolumn{11}{|c|}{ Project Phase-Consumption Estimate-Lighting } \\
\hline Data Sheet & Description & $\begin{array}{l}\text { Family and } \\
\text { Type }\end{array}$ & Quantity (n) & Spotlight (n) & $\begin{array}{l}\text { Spotlight } \\
\text { Power (W) }\end{array}$ & Type Power (W) & $\begin{array}{l}\text { Total Power } \\
\text { (W) }\end{array}$ & $\begin{array}{l}\text { Hours of Use } \\
\text { (h) }\end{array}$ & Days of Use (n) & $\begin{array}{l}\text { Annual } \\
\text { Consumption } \\
\text { (Wh) }\end{array}$ \\
\hline STF-A_004.1 & Streetlight & LMP_01: H_4m & 3 & 1 & 60 & 60 & 180 & 10 & 365 & 657,000 \\
\hline STF-A_004.2 & Streetlight & LMP_02: H_6m & 18 & 1 & 80 & 80 & 1440 & 10 & 365 & $5,256,000$ \\
\hline STF-A_004.3 & Streetlight & $\begin{array}{l}\text { LMP_03: H_6m - } \\
\text { 3_Proiettori }\end{array}$ & 4 & 3 & 100 & 300 & 1200 & 10 & 365 & $4,380,000$ \\
\hline STF-A_004.4 & Streetlight & LMP_04: H_3m & 2 & 1 & 80 & 80 & 160 & 10 & 365 & 584,000 \\
\hline STF-A_004.5 & Streetlight & LMP_05: H_3m & 12 & 1 & 100 & 100 & 1200 & 10 & 365 & $4,380,000$ \\
\hline STF-A_004.7 & Streetlight & $\begin{array}{l}\text { LMP_07: H_6m - } \\
\text { 1_Proiettore }\end{array}$ & 3 & 1 & 100 & 100 & 300 & 10 & 365 & $1,095,000$ \\
\hline STF-A_004.8 & Streetlight & $\begin{array}{l}\text { LMP_07: H_6m - } \\
\text { 2_Proiettori }\end{array}$ & 1 & 2 & 100 & 200 & 200 & 10 & 365 & 730,000 \\
\hline STF-A_005.1 & $\begin{array}{l}\text { Light tower } \\
\text { with platform }\end{array}$ & $\begin{array}{c}\text { TRF_P_01: } \\
\text { H_12m - } \\
\text { 7_Proiettori }\end{array}$ & 1 & 7 & 250 & 1750 & 1750 & 10 & 365 & $6,387,500$ \\
\hline STF-A_005.2 & $\begin{array}{l}\text { Light tower } \\
\text { with platform }\end{array}$ & $\begin{array}{l}\text { TRF_P_02: } \\
\text { H_12m - } \\
\text { 3_Proiettori } \\
\text { TRF P 03: }\end{array}$ & 1 & 3 & 250 & 750 & 750 & 10 & 365 & $2,737,500$ \\
\hline STF-A_006.1 & Light tower & $\begin{array}{l}\text { TRF_01: H_12m } \\
\text { - 3_Proiettori }\end{array}$ & 7 & 3 & 250 & 750 & 5250 & 10 & 365 & $19,162,500$ \\
\hline STF-A_006.2 & Light tower & $\begin{array}{l}\text { TRF_01: H_12m } \\
\text { - 5_Proiettori }\end{array}$ & 6 & 5 & 250 & 1250 & 7500 & 10 & 365 & $27,375,000$ \\
\hline STF-A_006.3 & Light tower & $\begin{array}{l}\text { TRF_02: H_12m } \\
\text { - 2_Proiettori }\end{array}$ & 1 & 2 & 250 & 500 & 500 & 10 & 365 & $1,825,000$ \\
\hline STF-A_006.4 & Light tower & $\begin{array}{l}\text { TRF_02: H_12m } \\
\text { - 3_Proiettori }\end{array}$ & 1 & 3 & 250 & 750 & 750 & 10 & 365 & $2,737,500$ \\
\hline STF-A_006.5 & Light tower & $\begin{array}{l}\text { TRF_03: H_12m } \\
\text { - 3_Proiettori }\end{array}$ & 2 & 3 & 250 & 750 & 1500 & 10 & 365 & $5,475,000$ \\
\hline STF-A_006.6 & Light tower & $\begin{array}{l}\text { TRF_04: H_12m } \\
\text { - 3_Proiettori }\end{array}$ & 1 & 3 & 250 & 750 & 750 & 10 & 365 & $2,737,500$ \\
\hline STF-A_007.1 & Signal light & FRR: H_4m & 1 & 1 & 100 & 100 & 100 & 10 & 365 & 365,000 \\
\hline \multirow[t]{3}{*}{ STF-A_007.2 } & Signal light & FRV: H_4m & 1 & 1 & 100 & 100 & 100 & 10 & 365 & 365,000 \\
\hline & & & & & & & 24,700 & & & $90,155,000$ \\
\hline & & & & & & & & & $\mathrm{kWh}$ & 90,155 \\
\hline
\end{tabular}


In Table 3 is reported the overall electrical consumption of all the devices.

Table 3. Electrical load for charging systems.

\begin{tabular}{|c|c|c|c|c|c|c|c|}
\hline \multicolumn{8}{|c|}{ Consumption Estimate-Electrical Device } \\
\hline Data Sheet & Description & Family and Type & Quantity (n) & Power (W) & Hours of Use (h) & Days of Use (n) & $\begin{array}{c}\text { Annual } \\
\text { Consumption } \\
\text { (Wh) }\end{array}$ \\
\hline STF-A_003.1 & Charging station & $\begin{array}{l}\text { CLL_01_QMC200B: } \\
\text { GW68832W }\end{array}$ & 2 & 4 & 10 & 90 & 7200 \\
\hline STF-A_003.2 & Charging station & CLL, 02: $4 \mathrm{P}$ & 5 & 4 & 10 & 90 & 18,000 \\
\hline STF-A_003.3 & $\begin{array}{c}\text { interlocked } \\
\text { socket }\end{array}$ & PRI: 2P, 01 & 10 & 4 & 10 & 90 & 36,000 \\
\hline STF-A_003.4 & $\begin{array}{l}\text { interlocked } \\
\text { socket }\end{array}$ & PRI: 2P, 02 & 15 & 4 & 10 & 90 & 54,000 \\
\hline STF-A_003.5 & $\begin{array}{l}\text { interlocked } \\
\text { socket }\end{array}$ & PRI: 3P & 2 & 4 & 10 & 90 & 7200 \\
\hline STF-A_003.6 & $\begin{array}{l}\text { interlocked } \\
\text { socket }\end{array}$ & PRI: 4P & 2 & 4 & 10 & 90 & 7200 \\
\hline
\end{tabular}

The total amount of optimizing electrical loads of the Anzio port area is 90,155+ $129,600=219,755 \mathrm{kWh}$ for a year. This is the target of implementing the RESs local grid production in the same place to reach a ZED (Figure 6).

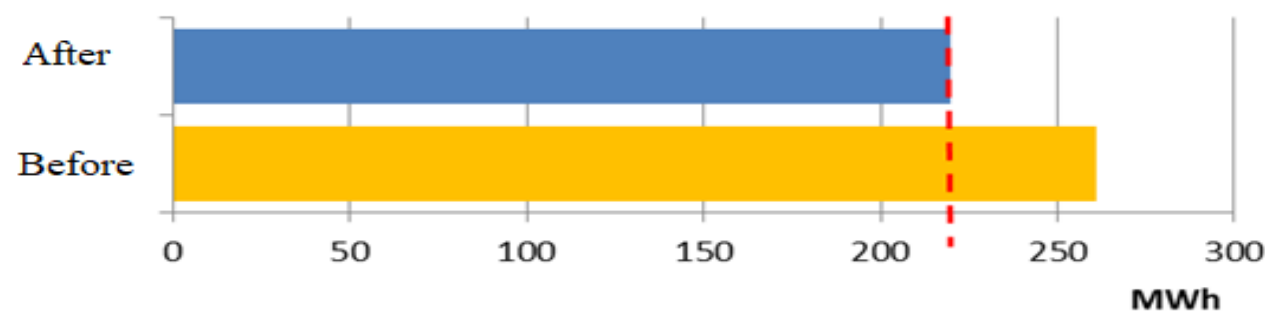

Figure 6. Electricity consumption of Anzio.

\subsection{Wind Energy Potential Assessment}

More than 40 years of monthly data from the MERRA-2 reanalysis dataset have been used to understand better the wind speed potential and mapping of port areas and understand the wind speed (Figures 7 and 8 ) in the case of micro wind turbines' installation.

Secondly, two sites have been located as ideal for the placement of the turbines [60]. The locations match the piers at the South and North ends of the harbour (Figure 9) for a total amount of fifteen turbines.

Ten wind turbines will be located next to the previous breakwater points, and the remaining five will follow the second breakwater lines.

The micro wind turbine DS3000 model (ETNEO Italia) was chosen to be installed at Anzio Port. DS3000 model is a $3 \mathrm{~kW}$ vertical axis micro-generator, equipped with a Savonius rotor mounted on the central axis of the turbine, valid for the starting of the rotation with low winds, and three Darrieus blades to increase the production with medium/strong winds. The Savonius blades, oriented on the four cardinal points to capture the wind from any direction, do not require the orientation of the rotor (Figure 10).

The annual average wind speed was calculated using the "Renewables. ninja" platform, which provides an hourly average wind speed [37]. For both Region of Interest (ROI), the obtained value at the height of $10 \mathrm{~m}$ is around $4.75 \mathrm{~m} / \mathrm{s}$ (data confirmed by the RSE Wind Atlas platforms and MERRA-2 reanalysis dataset) [60-62]. Regarding calculating the turbine's annual energy production, a reference was made to the data estimated by the supplier ETNEO Italia, as shown in Table 4. 


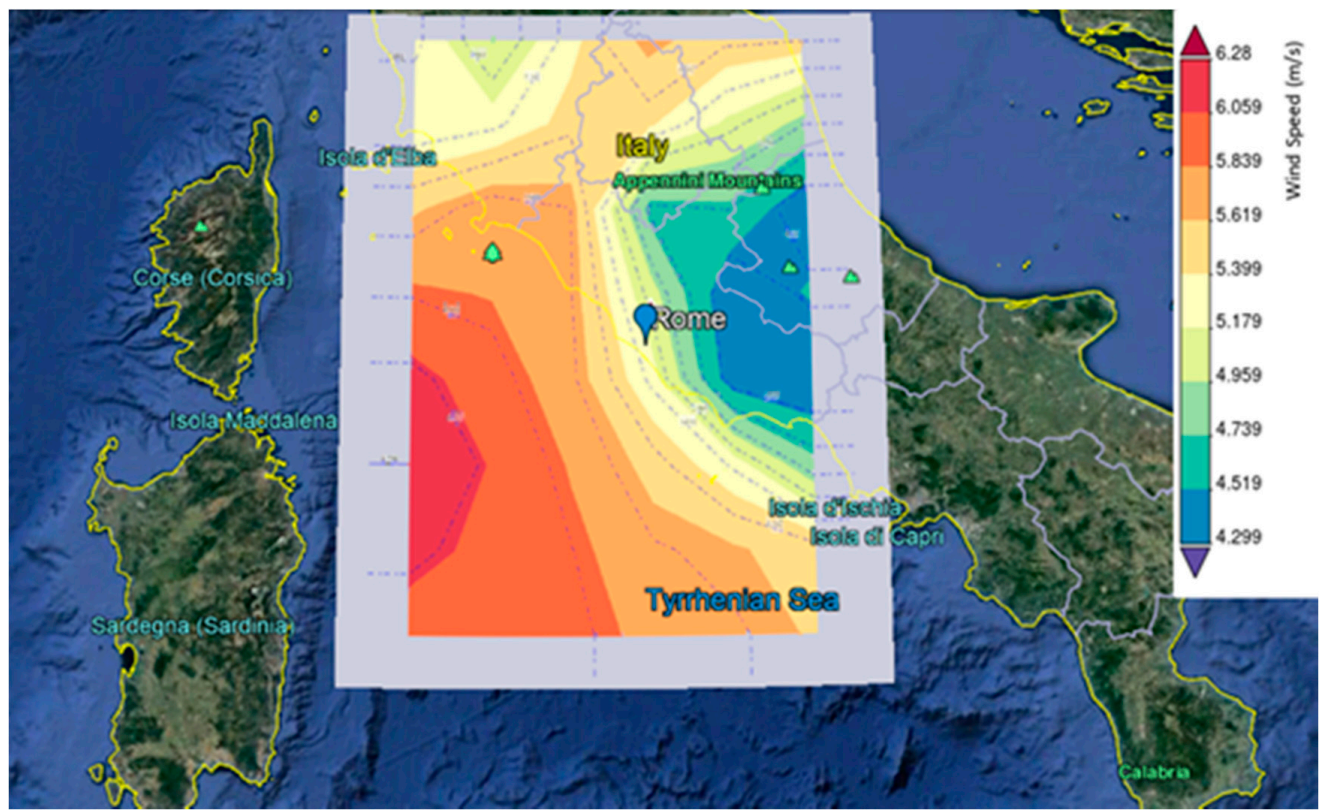

Figure 7. Surface wind speed $(\mathrm{m} / \mathrm{s})$ in the Rome City and Anzio port showed a blue point for 1980 to 2021.

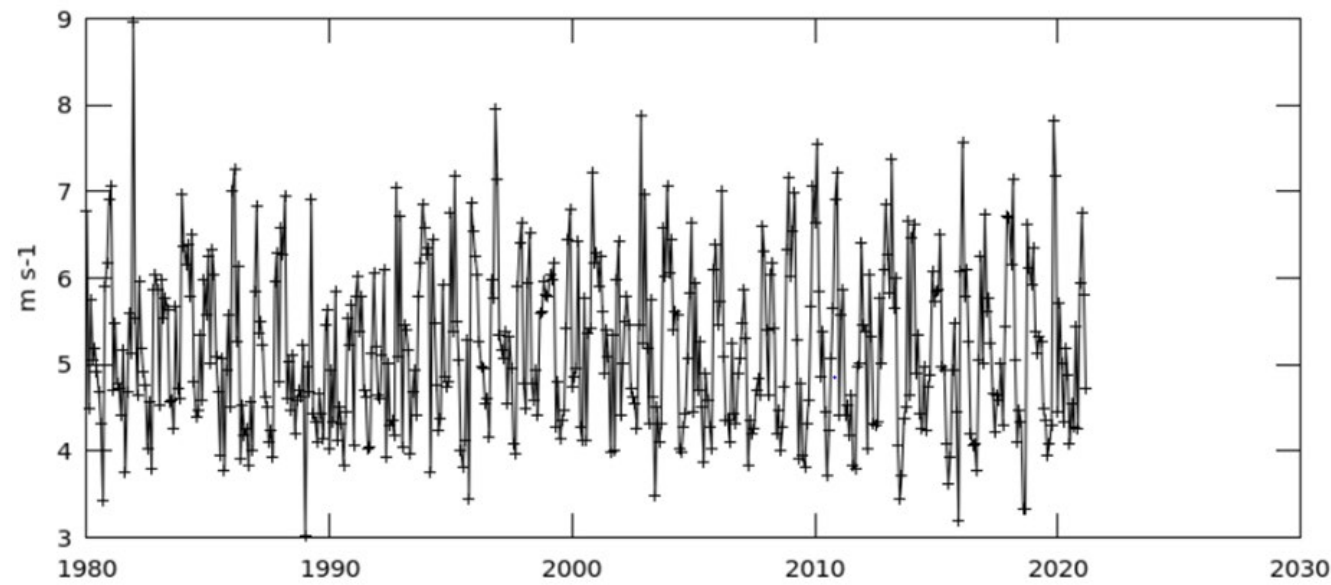

Figure 8. Showed a monthly time-series analysis between 1980 to 2021 for the Anzio port.

With the power curve in MATLAB the energy value produced by the calculating turbine for a vehicle speed of $4.75 \mathrm{~m} / \mathrm{s}$ is approximately $2420 \mathrm{kWh}$. Fifteen micro wind turbines are located in external port areas, as shown in Figure 9 as an example. Therefore, the obtained value is approximately $2420 \mathrm{kWh}$ per year. Therefore, it is possible to produce $36,300 \mathrm{kWh}$ per year with fifteen turbines located on the outer side of the pier (Figure 9). Specifically, a spline has been selected as the appropriate interpolation function, as shown in the curve in Figure 11. 


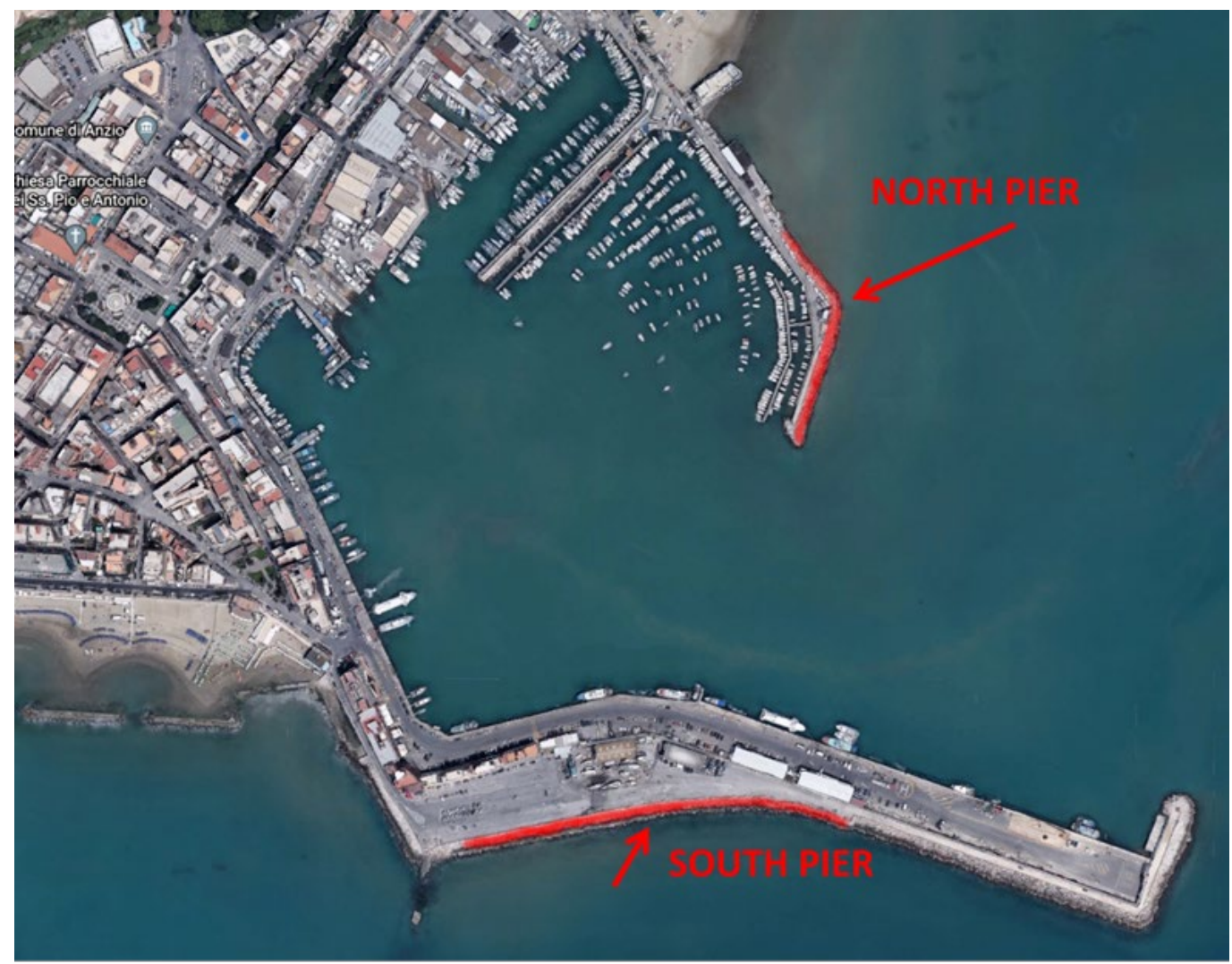

Figure 9. The micro-wind turbine installation locations.

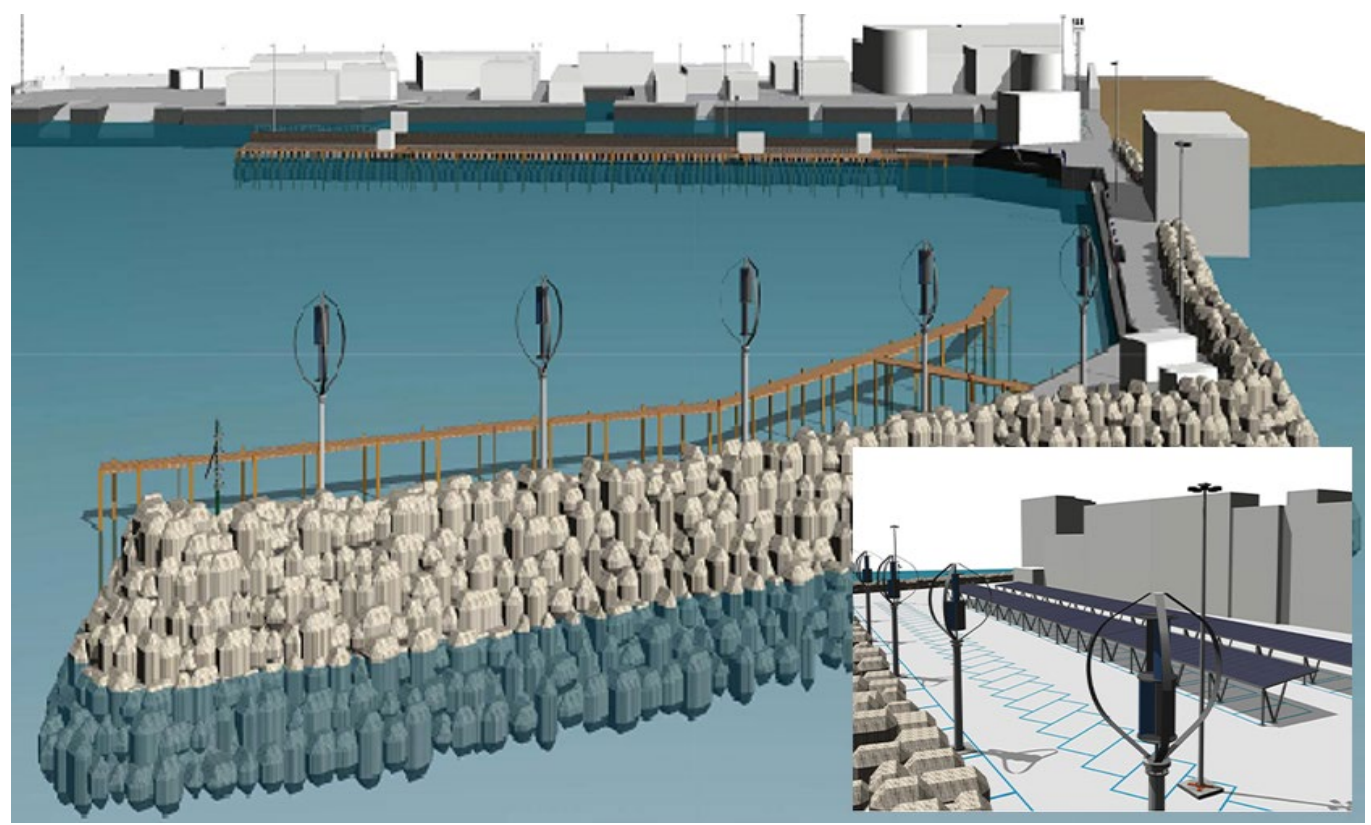

Figure 10. Turbines BIM Model. 
Table 4. Turbine's Annual Energy Production (AEP).

\begin{tabular}{cc}
\hline Average Wind Speed $(\mathbf{m} / \mathbf{s})$ & AEP $\mathbf{( k W h )}$ \\
\hline 5 & 2.851 \\
\hline 5.5 & 3.819 \\
\hline 6 & 4.877 \\
\hline 6.5 & 5.975 \\
\hline 7 & 7.061 \\
\hline 7.5 & 8.088 \\
\hline 8 & 8.945 \\
\hline
\end{tabular}

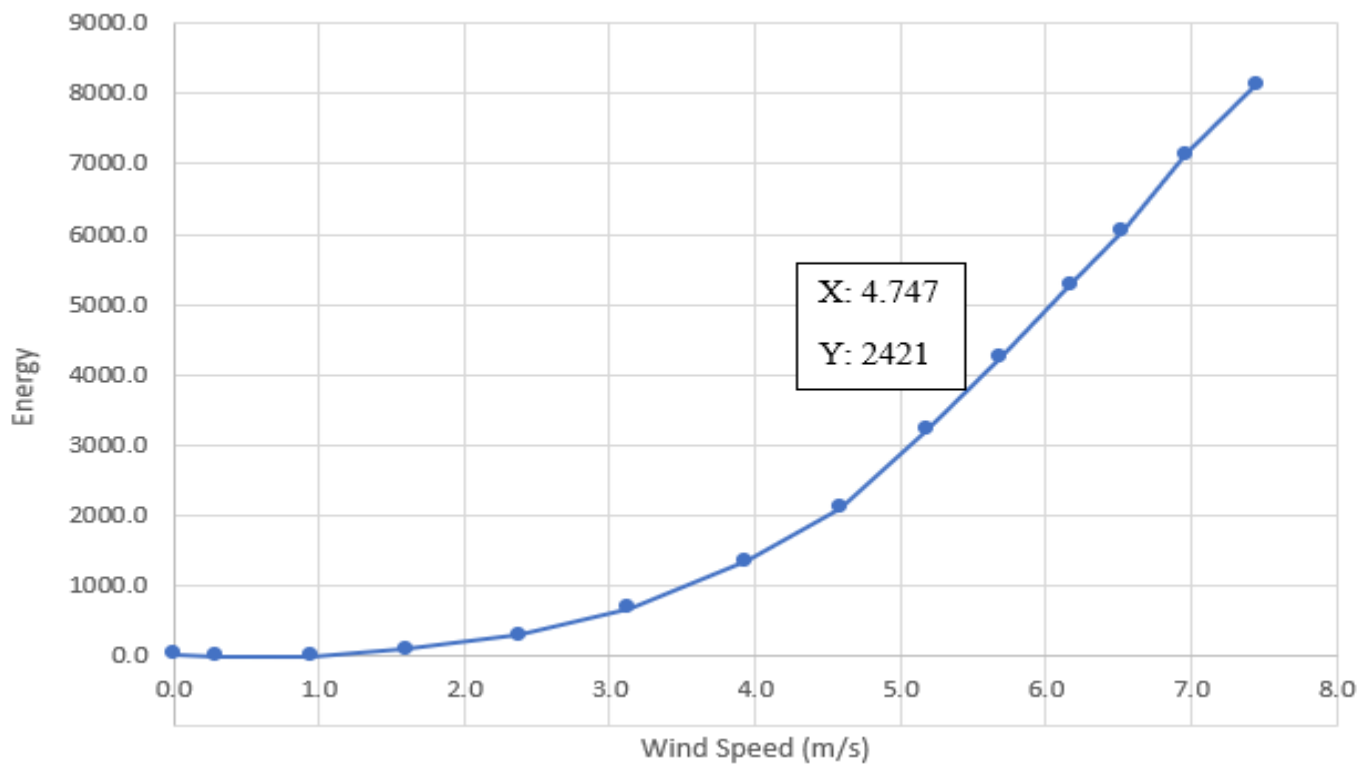

Figure 11. Turbine production data.

\subsection{Solar Energy Assessment (PV System)}

More than 40 years of monthly data from the MERRA-2 reanalysis dataset have been used to map PV solar irradiation analysis mapping of port areas with exciting potential to evaluate the solar irradiation potential (Figures 12 and 13) for PV installation.

Secondly, electric power production from a solar source should be performed by positioning a dedicated PV panel directly on the ground in port areas without significant cars. The technology of solar roads rapidly increases its penetration, especially on infrastructures and installation characterized by wide spaces without buildings and people presence [63-65].

For installing the photovoltaic modules, the area at the end of the southern pier was chosen. It's a large area, characterized by good exposure and without shading (there are no buildings nearby), as shown in Figure 14, with indicated in the red zone with the arrow. Let's consider the latter solution: the parking area identified is shown in the figure. It is an area of about $800 \mathrm{~m}^{2}$, with parking spaces oriented at $30^{\circ}$ to the south.

Photovoltaic canopies are car park covers that have the dual purpose of covering parked vehicles and generating clean energy. They are mainly made of galvanized steel, a highly resistant material supporting the photovoltaic module system. The photovoltaic system for electricity production is placed on the sloping roof, which can be connected to the grid or even to the charging columns of parked electric cars (Figures 14 and 15). These systems protect cars from prolonged exposure to the sun, transforming a potentially harmful agent for the car into a source of clean energy. 


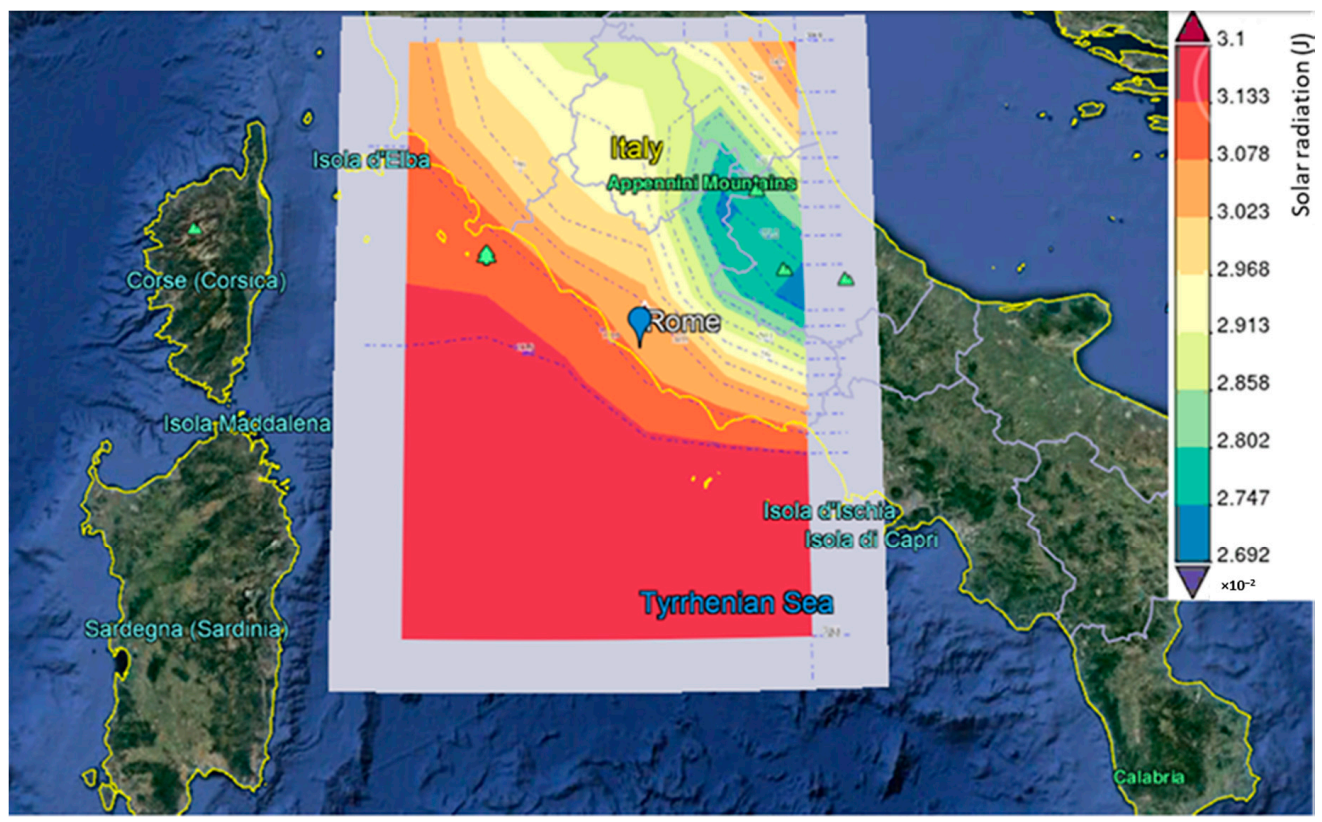

Figure 12. Solar irradiation in the Rome City and Anzio port showed a blue point from 1980 to 2020.

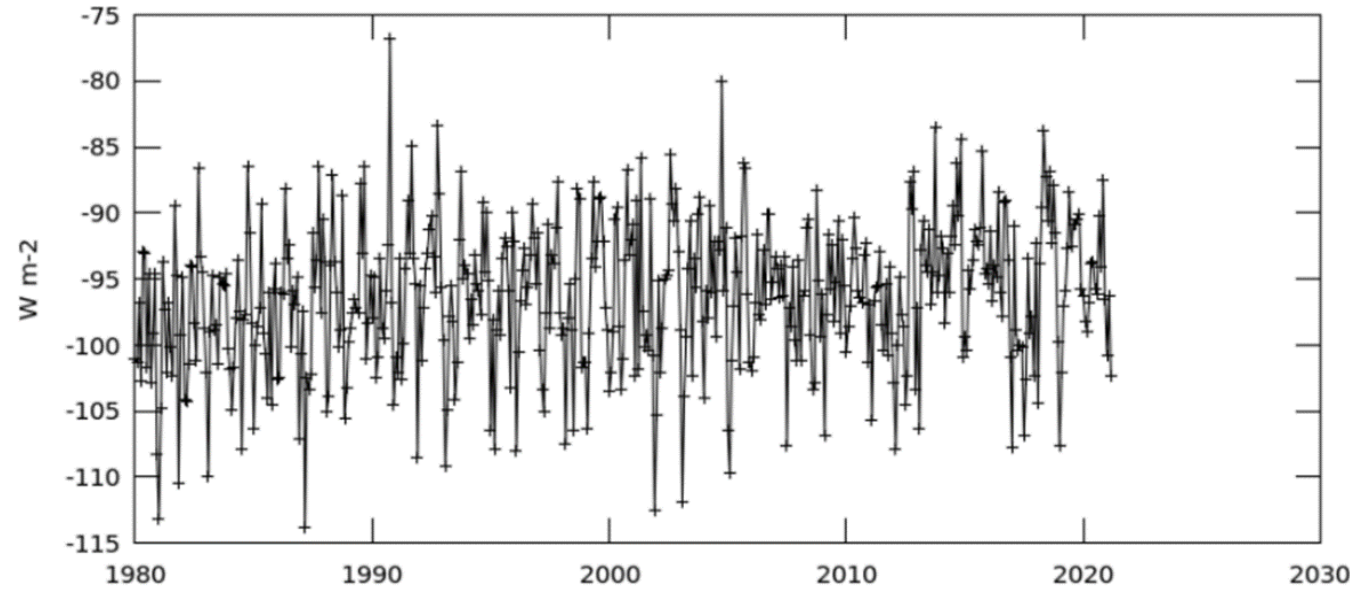

Figure 13. Showed a monthly time-series analysis between 2019 to 2020 for the Anzio port.

The structure also offers shelter from precipitation, hail and snow. From the data collected in the literature, the modules used for solar asphalt have average yields of around $9 \%$. The performance of this technology is lower than standard modules, but it is still worth studying its application in the port also in the perspective of future technological advances. To cover the remaining energy requirement, the peak power required to be available is approximately $150 \mathrm{kWp}$.

The orientation and inclination have been set to $0^{\circ}$, and also the "integrated in the building" option has been chosen as the mounting position. From the calculation performed with PVGIS, the energy produced is equal to $186,254.63 \mathrm{kWh}$ per year. The results were obtained from the simulation for the $150 \mathrm{kWp}$ plant.

To estimate the energy production of the PV shelters, the azimuth angle of the car parks has been inserted as the "tilt" angle of the wall unit's design. The energy produced per $\mathrm{kW}$ is much greater than in the previous case $(1334.22 \mathrm{kWh} / \mathrm{kW}$ compared to $1241.69 \mathrm{kWh} / \mathrm{kW}$ of the solar asphalt).

A single shelter with $P_{p p}=9 k$ the PV system peak power. Taking into account the rounding up, the shelters produce a total of 192.13 MWh per year, with a total peak power of $144 \mathrm{kWp}$. 


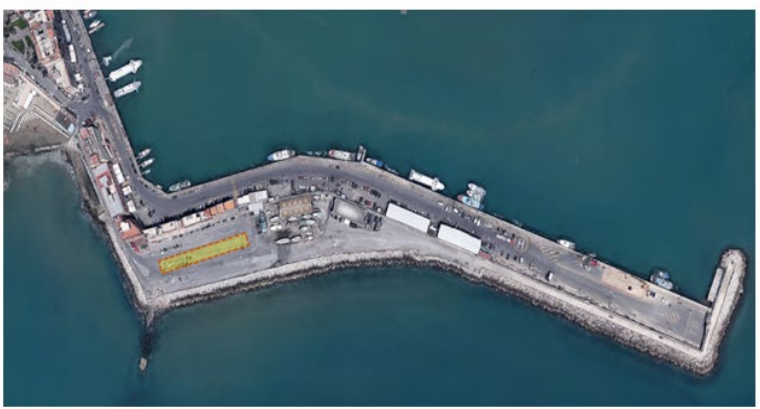

a)

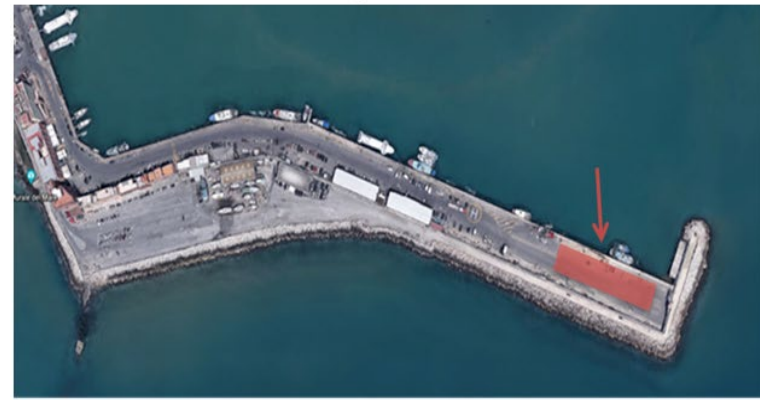

c)

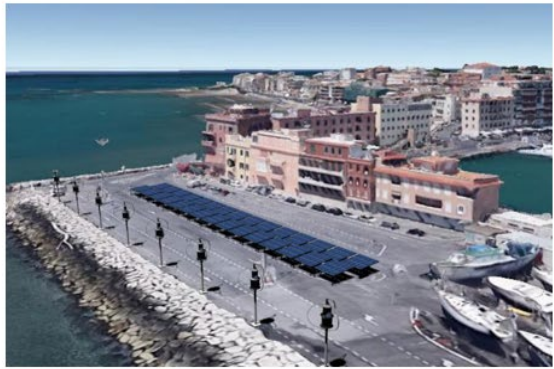

b)

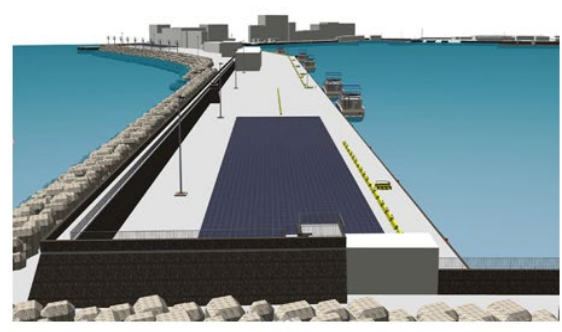

d)

Figure 14. (a,b) Photovoltaic (PV) solar asphalt area, (c,d) PV asphalts.

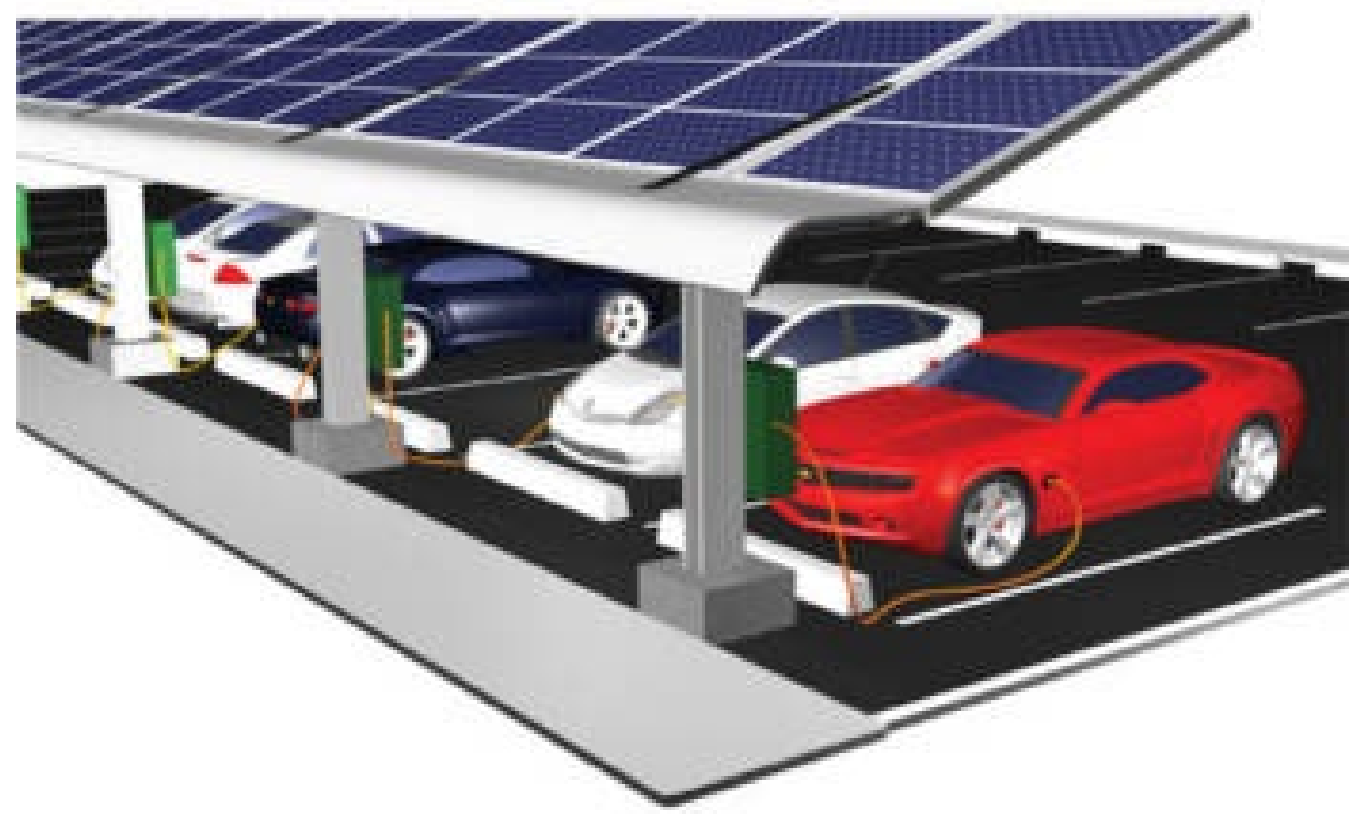

Figure 15. Photovoltaic shelters.

\subsection{Energy Produced Balance}

As shown in the pie chart, the energy contribution of wind turbines is significantly lower than that of solar asphalt (Figure 16 and Table 5). The goal of transforming the area into a ZED has been achieved. The optimized annual energy requirement of the port area is fully covered by the on-site production of wind and photovoltaic systems. 


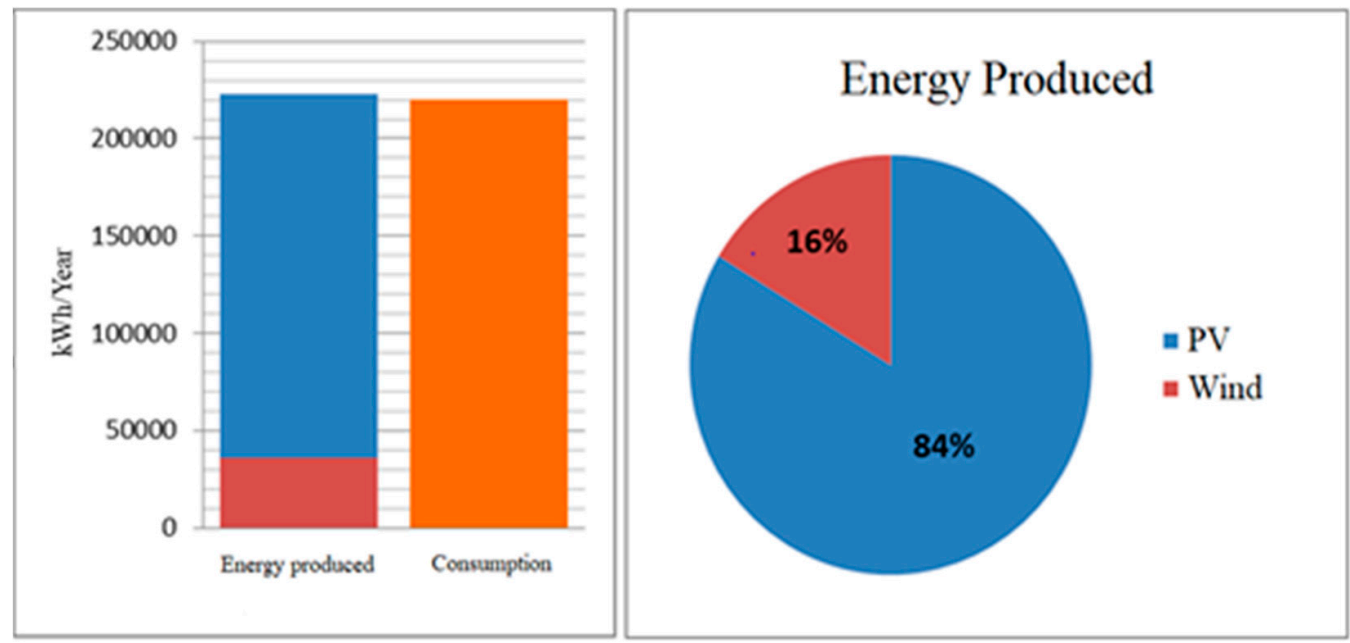

Figure 16. Comparison of consumption - energy produced by RES (Left), Subdivision of energy produced by RES (Right).

Table 5. Annual production of energy from RESs.

\begin{tabular}{ccc}
\hline \multicolumn{3}{c}{ Annual Energy Production of FER-Anzio } \\
\hline FER & Technology & kwh/year \\
\hline PV & Asphalt PV & $186,254.63$ \\
\hline Wind & wind turbine & 36,300 \\
\hline & & $222,554.63$ \\
\hline
\end{tabular}

\section{5. $\mathrm{CO}_{2}$ Emissions}

The energy upgrading of the port area can significantly contribute to the reduction of $\mathrm{CO}_{2}$ emissions and the reduction of energy absorption from the national electricity grid. The calculation of avoided $\mathrm{CO}_{2}$ emissions consists of the electricity generated from RESs by the average annual $\mathrm{CO}_{2}$ emission factor associated with the electricity grid.

The table with the emission factors, taken from the guidelines of the "Joint Research Center", shows the quantity in tons of $\mathrm{CO}_{2}$ emitted per MWh of energy produced by some energy carriers (Table 6):

Table 6. Emission factors.

\begin{tabular}{cc}
\hline $\mathrm{CO}_{2}$ Emission & Amount \\
\hline Gas & 0.202 \\
\hline Diesel & 0.267 \\
\hline Electric tariffs & 0.276 \\
\hline
\end{tabular}

An additional quantity of $\mathrm{CO}_{2}$ not emitted into the environment should be added, i.e., that of the boats that would use the recharging service through the columns installed along the quays of the port (whose $\mathrm{CO}_{2}$ emission factors from the electricity network are in any case lower than those of conventional fuels) (Figure 17).

Unfortunately, the estimation of the "carbon footprint" applied to boats parked on the quay or when approaching/leaving the port is a rather complex operation since the data relating to the turnout of boats in the harbour are not available. Nevertheless, the measures adopted should be the environmental benefit to the lack of pollutants such as $\mathrm{PM}_{2.5}$ and NOx from boats. 


\section{$\mathrm{CO} 2$ Emission}

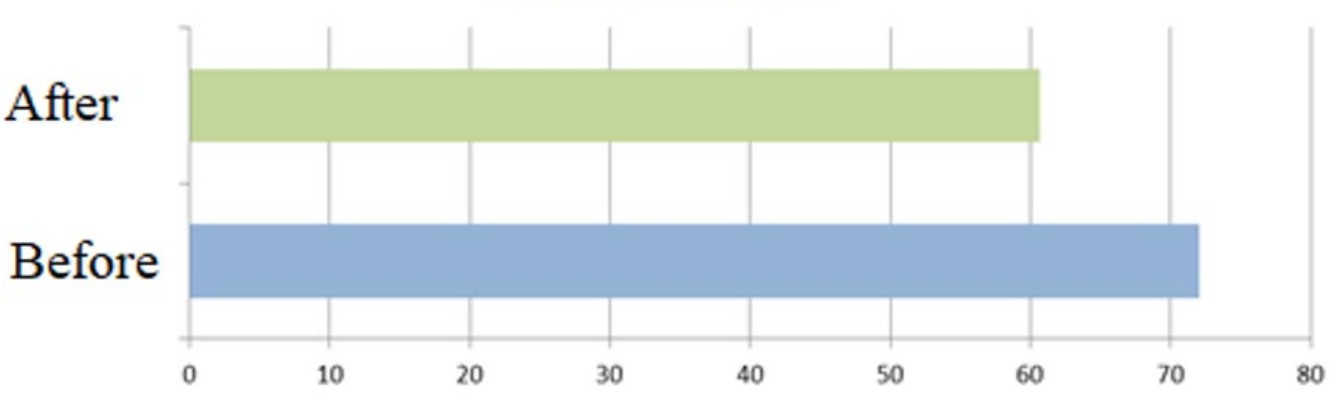

Figure 17. $\mathrm{CO}_{2}$ emissions before and after construction.

\subsection{Economic Evaluation}

In this paragraph, we will limit ourselves to making an account of the investment costs relating to installing wind and PV systems. As already explained above, there are no reliable references in the literature concerning the costs of solar asphalt technology. Therefore, for the economic analysis, reference will be made to the installation costs of the photovoltaic shelters. For the latter, the $9 \mathrm{~kW}$ model from Kit. Solutions were chosen from the quotes consulted online. The cost of each cover amounts to $€ 19,650$. Regarding the micro-wind plant, the price list was provided to us by the supplier company Etneo Italia Srl. From the quotation of the bidding company (Table 7), it appears:

Table 7. Cost of turbine components.

\begin{tabular}{cc}
\hline RES & Cost \\
\hline DS3000 Turbine & $9600 € / \mathrm{cad}$ \\
\hline On grid turbine & $2350 € / \mathrm{cad}$ \\
\hline Huawei inverter $4 \mathrm{~kW}$ & $1250 € / \mathrm{cad}$ \\
\hline Total & $13,200 € / \mathrm{cad}$ \\
\hline
\end{tabular}

The calculation of expenses is shown in the Table 8 below:

Table 8. RESs cost.

\begin{tabular}{cccccccc}
\hline FER & $\begin{array}{c}\mathbf{P}_{\mathbf{n}} \\
{\left[\mathbf{k W} \mathbf{p}_{\mathbf{p}}\right]}\end{array}$ & Amount $[\mathbf{n}]$ & $\begin{array}{c}\mathbf{P}_{\mathbf{p}} \mathbf{p l a n t} \\
{\left[\mathbf{k W} \mathbf{W}_{\mathbf{p}}\right]}\end{array}$ & $\begin{array}{c}\text { Energy Produced } \\
{[\mathbf{k W h} / \text { Year] }}\end{array}$ & $\begin{array}{c}\text { Energy Produced } \\
\text { Plant [kWh/Year] }\end{array}$ & Cost [€] & Total Cost $[\boldsymbol{\epsilon}]$ \\
\hline PV & 9 & 16 & 144 & 12,008 & 192,128 & 19,650 & 314,400 \\
\hline Turbine & 3 & 15 & 45 & 2420 & 36,300 & 13,200 & 198,000 \\
\hline
\end{tabular}

The overall cost of the infrastructure installed is, therefore, equal to 512,400 euros. This expense must be added to that relating to installation, which we assume equal to $45 \%$ of the cost of the devices (Table 9):

Table 9. Total investment.

\begin{tabular}{cccc}
\hline & Cost [€] & FPO [€] & Total Investment [€] \\
\hline PV Shelters & 314,400 & 141,480 & 455,880 \\
\hline Turbine & 198,000 & 89,100 & 287,100 \\
\hline & & & 742,980 \\
\hline
\end{tabular}

For micro-wind turbines, there are state incentives that concern the production of energy and not the installation of the system and are provided by the Energy Services 
Manager (GSE). This means that the return on investment is more significant the more energy is produced (if the wind turbine is located in a windy area). The two methods of incentive proposed are the all-inclusive rate and the "exchange on-site". All-inclusive tariff involves a gain of EUR0.30 for each $\mathrm{kWh}$ fed into the national grid and has a duration of 15 years, after which one can access the free market or the so-called "dedicated collection". The "exchange on-site" incentive is more suitable for small plants.

In this case, the gain amounts to EUR0.20 per kWh without time constraints. The calculation mechanism consists of the difference between the energy produced and the energy consumed: if the result is negative, it is charged to the bill. If positive, there is an energy "credit" scalable on future billing. In addition to the GSE incentives just outlined, for the installation of RES plants, such as wind power, the 2020 Budget Law allows a tax deduction of $65 \%$ (micro-generators) up to a maximum expenditure of EUR100 thousand. Photovoltaic systems on canopies are always a convenient solution, even without the incentives of the energy bill. In fact, by exploiting the "Exchange on-site" and sizing the system concerning actual consumption, thus aiming for self-consumption, it is possible to reduce the electricity bill significantly.

\section{Discussion}

Energy efficiency is one of the hot research topics that advances in existing technology directly affect future research prospects [66]. In this case, innovative approaches, economic analysis [67], operations optimization, the new technological advances effects [68], and management analysis will be the most important for future ports research. Economic and environmental analysis for automated and electric ports are also necessary and inevitable [69]. Therefore, integrating independent and electrical equipment with energy storage devices makes smart meters more potent and straightforward, making the significant range possible for further analysis [70]. Next-generation ports will use automation, electricity and intelligent energy management systems. To this aim, the role of independent or electric vehicles in the smart grid is unavoidable, which should be further discussed for future port operations.

Energy management can be considered one of the management tools prominent features to move ports towards greater sustainability with the environment and reduce greenhouse gases. That is why energy management in ports is more focused on Environmental Management Systems (EMS). For example, the European Maritime Ports Organization (ESPO) supports and encourages European ports to develop environmental management programs [3], but EMS is only approved by half of the European ports. Therefore, interaction with shareholders can be considered basic and essential to implement EMS in ports better [33].

The ports' main challenges in the EMS development can be identified in the following cases; (1) balancing economic and environmental goals in ports and (2) sharing knowledge and joint production and successful experiences in national and international ports [71]. In this regard, several ports define specific programs for energy management, which can be considered with the protection policies of the European Union, including projects for the renewable energy use to reduce air and environmental pollution [27].

Managing sustainable energy development using RESs is an emerging issue for ports [12]. In this regard, a conceptual framework for energy management systems, similar to the model in their construction, can be very effective [72]. Unfortunately, there are no studies analyzing barriers to energy efficiency in ports. These barriers to energy efficiency in ports include most technical, economic and regulatory aspects. There are also barriers to the supply of clean fuels and other technologies [1], so barrier analysis is invaluable to industry and academia. In the port industry literature, most technical reports explain the RESs use.

Researchers can focus on intelligent grid analysis and evaluate smart grids operational and environmental performance using simulation tools. Balancing energy demand and supply in the smart grid is a complex task [73]. Furthermore, more research in the initial 
step should have high data quality to perform a successful analysis. Assessing and evaluating aspects of monitoring has benefits for ports, (i) assessing the level of environmental pollution in ports, (ii) improving the environmental and energy management impacts, and (iii) helping to reform port strategies and policies, (v) the possibility of evaluating energy consumption studies and environmental risk management in ports to estimate and determine practical goals and measures in the future [74,75].

In this regard, to support decision-makers and port managers in selecting and implementing sustainable technologies, the need for actual empirical research and accurate implementation of the tools selection, technologies and operations [76]. Hence, there is a need to transfer more practical information from the scientific community to decision-makers to help port decision-makers. Furthermore, this knowledge transfer to port decision-makers who have more experience in implementation decisions will help them make the final decision [77].

Furthermore, conducting studies that act as a guide by considering the necessary standards can be very useful in developing a strategy to reduce GHG emissions in ports [78]. These studies can be used from a technical point of view, availability and cost analysis of alternative energy technology study with new development, evaluation, and implementation that increase regulatory regulations in ports [35]. The proposed DT framework aims to configure a digital integrated and multi-scale database for simulation purposes. It is intended to be integrated into real-time data from sensors and improve data management.

\section{Conclusions}

The project proposed presents an Anzio port digital transformation process of the Lazio Region, starting from their infrastructural centre. The implications of this transformation directly concern the environmental, economic and social spheres, setting the port area as the epicentre and extending to the city. The port has potential for public buildings, water sports schools, boat workshops and association headquarters, not the subject of this paper, which can be incorporated into the DT. Due to their geometric characteristics and location, a maximum of two-level buildings is easily transformable into ZEB buildings. A further implementation of the DT and extending the harbour representation can improve its environmental and economic management.

The data can be entered into a BIM and GIS environment within a sharing platform predictive scenario derived, and the urban fabric resilience with the creation and use of appropriate tools can be estimated. This allows planning in a well conscious way, respecting environmental sustainability and interventions aimed at economic, commercial and social activities. Critical from a design and then construction point of view is the cost estimate accuracy of interventions in such a critical area. Together with the costs, it is fundamental to estimate and plan the risks related to the execution of works, which will change the social impact during their implementation.

The "Port of Anzio" DT implementation digitalization area makes it possible to start from the digital and ecological transformation epicentres and spread throughout the territory. The exchange flows studying with the surrounding territories, linked to transport by sea, land, road, and rail. It would also replace electricity production's economic and environmental costs for public lighting and electricity supply to moored boats by switching from carbon to renewable energy sources.

With repercussions in all fields, this digital transformation will open new scenarios and higher efficiency in managing public finances, especially in the green deal area. There will be substantial energy and environmental benefits already in the construction phase of the works. In the planning and design phase, it will be possible to accurately assess various implications related to the implementation of the work and its territorial, environmental, and social context. The other important factor is the possibility of minimising the project's costs by simulating different scenarios. This means monetary, environmental, and social costs, not least those due to the construction times uncertainty. This factor scares off potential private, national, and international investors. That can be predicted by adding 
more future factors such as horizontal transport infrastructure, roads and railways; the parameters will significantly increase the analytical data volume under study. Therefore, the data analysis with current methods will be very time consuming and complex. So, given the data diversity, such studies require a rigorous data management method and analysis to define a digital structure integration approach

Various ports appear to have attempted to install intelligent energy management systems. However, it should be borne in mind that the systems effectiveness in different ports is directly related to the port's geographical location. This relationship varies according to the RESs availability and their type for efficiency in ports. On the other hand, various studies show that evaluating new measures and technologies with a high potential for intelligent energy management systems concerning sustainable and long-term goals is very effective.

In this regard, it can be said that the lack of cooperation between stakeholders and decision-makers is the main reason for stopping various projects in ports. In addition, despite the increase in academic studies on port sustainability, the exploitation of real-world research results in port infrastructure has not yet been well implemented. The main reason for this can be the lack of case studies with regional diversity in small ports. The central gap that should be considered in future studies is the energy efficiency report of a technology or techniques studied in ports. This may indicate the need to combine existing and new measures and technologies to promote the ZEDs concept design in leading studies.

Author Contributions: Conceptualization, S.A.; methodology, S.A., F.C., M.M.N., G.O. and G.P.; formal analysis, S.A., F.C. and M.M.N.; investigation, M.M.N.; resources, M.M.N., G.O. and G.P.; data curation, S.A., F.C. and M.M.N.; writing - original draft preparation, S.A., F.C. and M.M.N.; writing-review and editing, M.M.N.; visualization, G.O. and G.P.; supervision, F.C. and G.P.; project administration, F.C. and G.P. All authors have read and agreed to the published version of the manuscript.

Funding: This research has been carried out within the project "An integrated multidisciplinary and multiscale digital approach fostering the decarbonisation of port areas" protocol RG12117A8A106E46, funded by Sapienza university of Rome.

Institutional Review Board Statement: Not applicable.

Informed Consent Statement: Not applicable.

Data Availability Statement: Not applicable.

Acknowledgments: The authors wish to thank Francesco Nardi for his important contribution to the research team. The authors also would like to thank online platforms for providing the open access data.

Conflicts of Interest: The authors declare no conflict of interest.

\author{
Abbreviations \\ BIM Building Information Modelling \\ GIS Geographic Information System \\ RESs Renewable Energy Systems \\ $\mathrm{CO}_{2}$ Carbon Dioxide \\ MWh Mega Watt Hour \\ GBS Green Building Studio \\ ROI Region of Interest \\ EC European Community \\ IoT Internet of Things \\ DT Digital Twin \\ ZED Zero Energy District \\ DTM Digital Twin Model \\ PVs Photovoltaics \\ LED Light-Emitting Diode
}




$\begin{array}{ll}\text { CFD } & \text { Computational Fluid Dynamics } \\ \text { IFC } & \text { International Foundation Class } \\ \text { AI } & \text { Artificial Intelligence } \\ \text { GHG } & \text { Greenhouse Gas } \\ \text { MERRA-2 } & \text { Modern-Era Retrospective analysis for Research and Applications, Version 2 } \\ \text { GSE } & \text { Energy Services Manager }\end{array}$

\section{References}

1. Barbarelli, S.; Amelio, M.; Florio, G.; Scornaienchi, N.M. Procedure Selecting Pumps Running as Turbines in Micro Hydro Plants. Energy Procedia 2017, 126, 549-556. [CrossRef]

2. Acciaro, M. Environmental sustainability in seaports: A framework for successful innovation. Marit. Policy Manag. 2014, 41, 480-500. [CrossRef]

3. Lam, J.S.L.; Notteboom, T. The Greening of Ports: A Comparison of Port Management Tools Used by Leading Ports in Asia and Europe. Transp. Rev. 2014, 34, 169-189. [CrossRef]

4. Nastasi, B.; Mazzoni, S.; Groppi, D.; Romagnoli, A.; Astiaso Garcia, D. Optimized integration of Hydrogen technologies in Island energy systems. Renew. Energy 2021, 174, 850-864. [CrossRef]

5. Groppi, D.; Nastasi, B.; Prina, M.G.; Astiaso Garcia, D. The EPLANopt model for Favignana island's energy transition. Energy Convers. Manag. 2021, 241, 114295. [CrossRef]

6. Yap, W.Y.; Lam, J.S.L. 80 million-twenty-foot-equivalent-unit container port? Sustainability issues in port and coastal development. Ocean Coast. Manag. 2013, 71, 13-25. [CrossRef]

7. Lam, J.S.L. Designing a sustainable maritime supply chain: A hybrid QFD-ANP approach. Transp. Res. Part E Logist. Transp. Rev. 2015, 78, 70-81. [CrossRef]

8. Gibbs, D.; Rigot-Muller, P.; Mangan, J.; Lalwani, C. The role of sea ports in end-to-end maritime transport chain emissions. Energy Policy 2014, 64, 337-348. [CrossRef]

9. Steenken, D.; Voß, S.; Stahlbock, R. Container terminal operation and operations research-A classification and literature review. OR Spectr. 2004, 26, 3-49. [CrossRef]

10. Bierwirth, C.; Meisel, F. A follow-up survey of berth allocation and quay crane scheduling problems in container terminals. Eur. J. Oper. Res. 2015, 244, 675-689. [CrossRef]

11. Nastasi, B.; Mazzoni, S.; Groppi, D.; Romagnoli, A.; Astiaso Garcia, D. Solar power-to-gas application to an island energy system Renew. Energy 2021, 164, 1005-1016. [CrossRef]

12. Woo, J.K.; Moon, D.S.H.; Lam, J.S.L. The impact of environmental policy on ports and the associated economic opportunities. Transp. Res. Part A Policy Pract. 2018, 110, 234-242. [CrossRef]

13. Wilmsmeier, G.; Spengler, T. Energy consumption and container terminal efficiency. FAL Bull. 2016, 350, 10. Available online: https://www.cepal.org/en/publications/list/date/2016?search_fulltext=container+terminal (accessed on 28 January 2021).

14. Parise, G.; Parise, L.; Malerba, A.; Pepe, F.M.; Honorati, A.; Ben Chavdarian, P. Comprehensive Peak-Shaving Solutions for Port Cranes. IEEE Trans. Ind. Appl. 2017, 53, 1799-1806. [CrossRef]

15. Lamagna, M.; Nastasi, B.; Groppi, D.; Rozain, C.; Manfren, M.; Astiaso Garcia, D. Techno-economic assessment of reversible Solid Oxide Cell integration to renewable energy systems at building and district scale. Energy Convers. Manag. 2021, $235,113993$. [CrossRef]

16. Ricci, A.; Janssen, W.D.; van Wijhe, H.J.; Blocken, B. CFD simulation of wind forces on ships in ports: Case study for the Rotterdam Cruise Terminal. J. Wind Eng. Ind. Aerodyn. 2020, 205, 104315. [CrossRef]

17. Zis, T.; North, R.J.; Angeloudis, P.; Ochieng, W.Y.; Bell, M.G.H. Evaluation of cold ironing and speed reduction policies to reduce ship emissions near and at ports. Marit. Econ. Logist. 2014, 16, 371-398. [CrossRef]

18. Wen, B.; Jin, Q.; Huang, H.; Tandon, P.; Zhu, Y. Life cycle assessment of Quayside Crane: A case study in China. J. Clean. Prod. 2017, 148, 1-11. [CrossRef]

19. Carlo, H.J.; Vis, I.F.A.; Roodbergen, K.J. Transport operations in container terminals: Literature overview, trends, research directions and classification scheme. Eur. J. Oper. Res. 2014, 236, 1-13. [CrossRef]

20. Claudius, C.; Hardt, J. LED Technology for Container Terminals. pp. 1-7. Available online: http://europa.eu/legislation_ summaries/energy/energy_efficiency/127064_de.htm (accessed on 28 January 2021).

21. Van Duin, J.H.R.; Geerlings, H.; Froese, J.; Negenborn, R.R. Towards a method for benchmarking energy consumption at terminals: In search of performance improvement in yard lighting. Int. J. Transp. Dev. Integr. 2017, 1, 212-224. [CrossRef]

22. Tang, H.S.; Qu, K.; Chen, G.Q.; Kraatz, S.; Aboobaker, N.; Jiang, C.B. Potential sites for tidal power generation: A thorough search at coast of New Jersey, USA. Renew. Sustain. Energy Rev. 2014, 39, 412-425. [CrossRef]

23. Neshat, M. Layout optimisation of offshore wave energy converters using a novel multi-swarm cooperative algorithm with backtracking strategy: A case study from coasts of Australia. Energy 2022, 239, 122463. [CrossRef]

24. Acciaro, M.; Ghiara, H.; Cusano, M.I. Energy management in seaports: A new role for port authorities. Energy Policy 2014, 71, 4-12. [CrossRef]

25. Filom, S.; Radfar, S.; Panahi, R.; Amini, E.; Neshat, M. Exploring wind energy potential as a driver of sustainable development in the southern coasts of iran: The importance of wind speed statistical distribution model. Sustainability 2021, 13, 7702. [CrossRef] 
26. Heydari, A.; Astiaso, D.; Keynia, F.; Bisegna, F.; De Santoli, L. A novel composite neural network based method for wind and solar power forecasting in microgrids Group Method of Data Handling. Appl. Energy 2019, 251, 113353. [CrossRef]

27. Boile, M.; Theofanis, S.; Sdoukopoulos, E.; Plytas, N. Developing a port energy management plan: Issues, challenges, and prospects. Transp. Res. Rec. 2016, 2549, 19-28. [CrossRef]

28. Song, S.; Poh, K.L. Solar PV leasing in Singapore: Enhancing return on investments with options. IOP Conf. Ser. Earth Environ. Sci. 2017, 67, 012020. [CrossRef]

29. Hamburg Port Authority. Hamburg Is Staying on Course-The Port Development Plan to 2025. Published by: Free and Hanseatic City of Hamburg-State Ministry of Economic Affairs, Transport and Innovation Hamburg Port Authority. 2012, pp. 1-98. Available online: http:/ / www.hamburg-port-authority.de (accessed on 28 January 2021).

30. Port of Rotterdam. 2021. Available online: https://www.portofrotterdam.com/en/doing-business/setting-up/existingindustry/energy-industry/sustainable-energy (accessed on 15 April 2021).

31. Port of Antwerp. 2021. Available online: https://businessinantwerp.eu/news/port-antwerp-working-today-energy-tomorrow (accessed on 15 April 2021).

32. Schipper, C.A.; Vreugdenhil, H.; de Jong, M.P.C. A sustainability assessment of ports and port-city plans: Comparing ambitions with achievements. Transp. Res. Part D Transp. Environ. 2017, 57, 84-111. [CrossRef]

33. Poulsen, R.-T.; Ponte, B.S.; Sornn-Friese, H. Environmental upgrading in global value chains: The potential and limitations of ports in the greening of maritime transport. Geoforum 2018, 89, 83-95. [CrossRef]

34. Fenton, P. The role of port cities and transnational municipal networks in efforts to reduce greenhouse gas emissions on land and at sea from shipping-An assessment of the World Ports Climate Initiative. Mar. Policy 2017, 75, 271-277. [CrossRef]

35. Sadek, I.; Elgohary, M. Assessment of renewable energy supply for green ports with a case study. Environ. Sci. Pollut. Res. 2020, 27, 5547-5558. [CrossRef]

36. Caglayan, D.G.; Ryberg, D.S.; Heinrichs, H.; Linßen, J.; Stolten, D.; Robinius, M. The techno-economic potential of offshore wind energy with optimized future turbine designs in Europe. Appl. Energy 2019, 255, 113794. [CrossRef]

37. Alavirad, S.; Mohammadi, S.; Golombok, M.; Haans, K. Interconnection and generation from a North Sea power hub-A linear electricity model. Int. J. Electr. Power Energy Syst. 2021, 133, 107132. [CrossRef]

38. Lindstad, H.E.; Eskeland, G.S. Environmental regulations in shipping: Policies leaning towards globalization of scrubbers deserve scrutiny. Transp. Res. Part D Transp. Environ. 2016, 47, 67-76. [CrossRef]

39. Bjerkan, K.Y.; Seter, H. Reviewing tools and technologies for sustainable ports: Does research enable decision making in ports? Transp. Res. Part D Transp. Environ. 2019, 72, 243-260. [CrossRef]

40. Talamo, C.; Paganin, G.; Atta, N.; Rota, F. Epistemic uncertainty, risk management and information: The role of the detailed design. Techne 2019, 18, 164-173. [CrossRef]

41. Fuldauer, E. Smarter Cities are Born with Digital Twins. 2019. Available online: https://tomorrow.city/a/smarter-cities-areborn-with-digital-twins (accessed on 10 April 2021).

42. Atta, N.; Dalla Valle, A.; Campioli, A.; Chiaroni, D.; Talamo, C. Construction technologies for sustainable affordable housing within fragile contexts: Proposal of a decision support tool. Sustainability 2021, 13, 5928. [CrossRef]

43. Talamo, C.; Pinto, M.R.; Viola, S.; Atta, N. Smart cities and enabling technologies: Influences on urban Facility Management services. IOP Conf. Ser. Earth Environ. Sci. 2019, 296, 012047. [CrossRef]

44. Centre for Digital Built Britain. 2020. Available online: https://www.cdbb.cam.ac.uk/what-we-do (accessed on 11 April 2021).

45. Talamo, C.; Atta, N.; Martani, C.; Paganin, G. L'integrazione delle infrastrutture urbane fisiche e digitali: Il ruolo dei "big Data". Techne 2016, 11, 217-225. [CrossRef]

46. Mancini, F.; Nastasi, B. Solar energy data analytics: PV deployment and land use. Energies 2020, 13, 417. [CrossRef]

47. Manfren, M.; Nastasi, B.; Tronchin, L.; Groppi, D.; Garcia, D.A. Techno-economic analysis and energy modelling as a key enablers for smart energy services and technologies in buildings. Renew. Sustain. Energy Rev. 2021, 150, 111490. [CrossRef]

48. Mohammadi, N.; Taylor, J.E. Smart city digital twins. In Proceedings of the 2017 IEEE Symposium Series on Computational Intelligence (SSCI), Honolulu, HI, USA, 27 November-1 December 2017; pp. 1-5. [CrossRef]

49. Paganin, G.; Talamo, C.; Atta, N. Knowledge management and resilience of urban and territorial systems. Techne 2018, 15, 124-133. [CrossRef]

50. Manfren, M.; Nastasi, B.; Groppi, D.; Astiaso Garcia, D. Open data and energy analytics-An analysis of essential information for energy system planning, design and operation. Energy 2020, 213, 118803. [CrossRef]

51. Manfren, M. Parametric energy performance analysis and monitoring of buildings—HEART project platform case study. Sustain. Cities Soc. 2020, 61, 102296. [CrossRef]

52. Mohammadi, S.; de Vries, B.; Schaefer, W. A Comprehensive Review of Existing Urban Energy Models in the Built Environment BTPlanning Support Systems for Sustainable Urban Development; Geertman, S., Toppen, F., Stillwell, J., Eds.; Springer: Berlin/Heidelberg, Germany, 2013; pp. 249-265.

53. Aste, N.; Buzzetti, M.; Caputo, P.; Manfren, M. Local energy efficiency programs: A monitoring methodology for heating systems. Sustain. Cities Soc. 2014, 13, 69-77. [CrossRef]

54. Satir, T.; Doğan-Sağlamtimur, N. The protection of marine aquatic life: Green Port (EcoPort) model inspired by Green Port concept in selected ports from Turkey, Europe and the USA. Period. Eng. Nat. Sci. 2018, 6, 120-129. [CrossRef]

55. Available online: https://www.britannica.com/place/Anzio (accessed on 28 January 2021). 
56. Available online: https:/ / en.wikipedia.org/wiki/Anzio (accessed on 28 January 2021).

57. Mohammadi, S.; Soleymani, S.; Mozafari, B. Scenario-based stochastic operation management of MicroGrid including Wind, Photovoltaic, Micro-Turbine, Fuel Cell and Energy Storage Devices. Int. J. Electr. Power Energy Syst. 2014, 54, 525-535. [CrossRef]

58. Hautala, K.; Järvenpää, M.E.; Pulkkinen, P. Digitalization transforms the construction sector throughout asset's life-cycle from design to operation and maintenance. Stahlbau 2017, 86, 340-345. Available online: https://onlinelibrary.wiley.com/doi/epdf/1 (accessed on 28 January 2021). [CrossRef]

59. Safamehr, H.; Rahimi-Kian, A. A cost-efficient and reliable energy management of a micro-grid using intelligent demand-response program. Energy 2015, 91, 283-293. [CrossRef]

60. Orlando, A.; Pagnini, L.; Repetto, M.P. Structural response and fatigue assessment of a small vertical axis wind turbine under stationary and non-stationary excitation. Renew. Energy 2021, 170, 251-266. [CrossRef]

61. Syawitri, T.P.; Yao, Y.F.; Chandra, B.; Yao, J. Comparison study of URANS and hybrid RANS-LES models on predicting vertical axis wind turbine performance at low, medium and high tip speed ratio ranges. Renew. Energy 2021, 168, 247-269. [CrossRef]

62. Manatbayev, R.; Baizhuma, Z.; Bolegenova, S.; Georgiev, A. Numerical simulations on static Vertical Axis Wind Turbine blade icing. Renew. Energy 2021, 170, 997-1007. [CrossRef]

63. Mirzanamadi, R.; Hagentoft, C.E.; Johansson, P. Coupling a Hydronic Heating Pavement to a Horizontal Ground Heat Exchanger for harvesting solar energy and heating road surfaces. Renew. Energy 2020, 147, 447-463. [CrossRef]

64. Yesner, C.; Jasim, A.; Wang, H.; Basily, B.; Maher, A.; Safari, A. Energy harvesting and evaluation of a novel piezoelectric bridge transducer. Sens. Actuators A Phys. 2019, 285, 348-354. [CrossRef]

65. Mirzanamadi, R.; Hagentoft, C.E.; Johansson, P. Numerical investigation of harvesting solar energy and anti-icing road surfaces using a hydronic heating pavement and borehole thermal energy storage. Energies 2018, 11, 3443. [CrossRef]

66. Lee, D.; Cheng, C.C. Energy savings by energy management systems: A review. Renew. Sustain. Energy Rev. 2016, 56, 760-777. [CrossRef]

67. Lam, J.S.L.; Ko, M.J.; Sim, J.R.; Tee, Y. Feasibility of implementing energy management system in ports. In Proceedings of the 2017 IEEE International Conference on Industrial Engineering and Engineering Management (IEEM), Singapore, 10-13 December 2017; pp. 1621-1625. [CrossRef]

68. Barbarelli, S.; Florio, G.; Lo Zupone, G.; Scornaienchi, N.M. First techno-economic evaluation of array configuration of selfbalancing tidal kinetic turbines. Renew. Energy 2018, 129, 183-200. [CrossRef]

69. Nakada, M. A Comparative Study on Two Types of Automated Container Terminal Systems. Comput. Appl. Shipp. Shipbuild. 1980, 7, 217-222.

70. Al-Alawi, B.M.; Bradley, T.H. Review of hybrid, plug-in hybrid, and electric vehicle market modeling Studies. Renew. Sustain. Energy Rev. 2013, 21, 190-203. [CrossRef]

71. Puente-Rodríguez, D.; van Slobbe, E.; Al, I.A.C.; Lindenbergh, D.E.D. Knowledge co-production in practice: Enabling environmental management systems for ports through participatory research in the Dutch Wadden Sea. Environ. Sci. Policy 2016, 55, 456-466. [CrossRef]

72. May, G.; Stahl, B.; Taisch, M.; Kiritsis, D. Energy management in manufacturing: From literature review to a conceptual framework. J. Clean. Prod. 2017, 167, 1464-1489. [CrossRef]

73. Coronado Mondragon, A.E.; Coronado, E.S.; Coronado Mondragon, C.E. Defining a convergence network platform framework for smart grid and intelligent transport systems. Energy 2015, 89, 402-409. [CrossRef]

74. Gonzalez Aregall, M.; Bergqvist, R.; Monios, J. A global review of the hinterland dimension of green port strategies. Transp. Res. Part D Transp. Environ. 2018, 59, 23-34. [CrossRef]

75. Kang, D.; Kim, S. Conceptual model development of sustainability practices: The case of port operations for collaboration and governance. Sustainability 2017, 9, 2333. [CrossRef]

76. Di Vaio, A.; Varriale, L. Management innovation for environmental sustainability in seaports: Managerial accounting instruments and training for competitive green ports beyond the regulations. Sustainability 2018, 10, 783. [CrossRef]

77. $\mathrm{Ng}$, A.K.Y. Port Decision Maker Perceptions on the Effectiveness of Climate Adaptation Actions. Coast. Manag. 2018, 46, 148-175. [CrossRef]

78. Nastasi, B. Renewable Hydrogen Potential for Low-carbon Retrofit of the Building Stocks. Energy Procedia 2015, 82, 944-949. [CrossRef] 